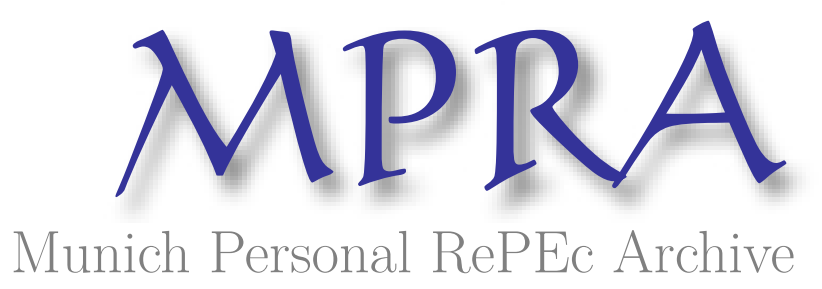

\title{
Comparing two financial crises: the case of Hong Kong real estate markets
}

LEUNG, K. Y. Charles and TANG, C. H. Edward

January 2011

Online at https://mpra.ub.uni-muenchen.de/31562/

MPRA Paper No. 31562, posted 15 Jun 2011 07:06 UTC 
Comparing two financial crises: the case of Hong Kong Real Estate Markets^

Charles Ka Yui Leung, City University of Hong Kong, kycleung@cityu.edu.hk

Edward Chi Ho Tang, City University of Hong Kong, edward.c.h.tang@gmail.com

This version: January 2011

\section{$\underline{\text { Abstract }}$}

Hong Kong is no stranger to bubbles or crisis. During the Asian Financial Crisis (AFC), the Hong Kong housing price index drops more than $50 \%$ in less than a year. The same market then experiences the Internet Bubble, the SARS attack, and recently the Global Financial Crisis (GFC). This paper attempts to provide some "stylized facts" of the real estate markets and the macroeconomy, and follow the event-study methodology to examine whether the markets behave differently in the AFC and GFC, and discuss the possible linkage to the change in government policies ("learning effect") and the flow of Chinese consumers and investors to Hong Kong ("China factor").

JEL classification Number: E44, E50, E60, G01, R20

Keywords: regime switching, structural change, small open economy, bounded rationality, banking policy

\footnotetext{
` The authors are grateful to (alphabetical order) Ashok Bardhan, Nan-Kuang Chen, Bob Edelstein, Cynthia Kroll, Fred Kwan, Francois Ortalo-Magne, Matthew Yiu, and many seminar participants for many inspiring discussions over the years. The financial support from the City University of Hong Kong is gratefully acknowledged. The usual disclaimer applies.
} 


\section{Introduction}

Real estate, once "necessity" goods in old times, becomes an investment vehicle nowadays. And if they are not probably managed, the consequences can be serious. For instance, real estate-related financial products, such as mortgage backed securities (MBS), and collateralized debt obligations (CDO), etc. are associated with the recent Global Financial Crisis (GFC) in 2008. Even without these products, the housing market deserves policy attention. A typical example is provided by the Hong Kong experience during the Asian Financial Crisis (AFC) in 1997. In 1997, Hong Kong was attacked by the speculators, who aimed at huge profits by participating both foreign exchange market and financial market. The Hong Kong Monetary Authority (HKMA) defended the fixed exchange rate by increasing the interest rate, which triggered a large impact in the asset markets. A decline in the real estate value hindered small businessmen to renew their bank loans and as a result, a contraction of the aggregate economy and an increase in unemployment rate were observed. In some extreme cases, some people committed suicide after they declared bankrupt. ${ }^{1}$

With such important consequence in mind, it is natural to ask a series of questions. Why HKMA needs to defend the exchange rate? Why HKMA chooses to defend it by increasing the interest rate? Why would the real estate price drop so dramatically? Is it "too high" before the crisis? How can the real estate price become "too high" in the first place? Did the Hong Kong market as well as government make changes so that the economy will become "less vulnerable" to financial crisis?

A small but emerging literature attempts to address these questions. On the empirical front, Ho and Wang (2006, 2008, 2009), Ho, Ma and Haurin (2008), Wong (2010), among others, attribute the "recession" after the AFC to the change of the public housing policy. They provide evidence that there is a "housing ladder" in Hong Kong: when people living in the public rental housing, which are not means-tested, accumulate enough savings, they will move to subsidized ownership schemes provided by the Hong Kong government. People who get richer will then move to the private market for even higher quality housing units. When the Hong Kong

1 Among others, see Chan et al (2005) and Chang et al (2009). 
government allowed the residents in the public rental housing to purchase their own houses, so-called "privatization of public housing," the demand for subsidized ownership quickly and significantly shrinks. The price of those units fall, and subsequently the price of private sector units fall as well. The aggregate consumption and investment contract and hence leads to a recession. Their empirical works verify the collateral-based housing ladder theory proposed by Ortalo-Magne and Rady (2006).

While the above series of papers is very insightful, it seems to be more specific to the Hong Kong experience. Yet many Asian economies experience adverse effects of the AFC. Therefore, there are several attempts to deepen the understanding of the relationship between a financial crisis and the real estate market on the theoretical front. For instance, Tse and Leung (2002) observe that during the AFC period, closed and small economies such as Taiwan experience a much smaller impact than open and small economies such as Hong Kong and Singapore. They therefore propose a simple theory in which the collateral constraint will have a much larger impact on the aggregate output when capital flows are free. Their theory also predicts that as small economies grow, they will allow for more capital flows and hence experience higher economic growth (and more volatility). Chen and Leung (2008), Jin, Leung and Zeng (2010) emphasize on the spillover effect between the commercial real estate and the residential real estate. When the real estate prices drop, the bank credit directed to the producers contract, especially for the small and medium size business. That leads to further reduction on real estate demand and hence leads to a further drop in real estate prices. Evidence based on the aggregate data (such as Chen and Leung, 2008; Jin, Leung and Zeng, 2010) and micro data (such as Leung, Lau and Leong, 2002; Leung and Feng, 2005), among others, find that this positive feedback mechanism seems to be able to account for the experience of Hong Kong, Japan, and even the recent history of the United States.

On the other hand, Chen, Chen and Chou (2010) emphasize on the consumption channel of the collateral effect. In their model, consumers would like to smooth out consumption over time. However, when the collateral value of their houses drop, the consumer credit they can receive decrease. The aggregate consumption drop will then be more significant than the case 
when the case when the consumers can freely borrow without any borrowing constraint. They find support from the Taiwan data.

In the media, AFC is often described as a "bubble period" and the recession after it is interpreted as a "correction." The theoretical analysis of Leung and Chen $(2006,2010)$ suggest another possibility. They construct an overlapping-generations model in which the land price and stock price can fluctuate over time even with invariant economic fundamentals. In other words, it may not be easy to dictate what the "fundamental-determined asset price" is and hence "bubble" could be confused with "normal fluctuations" of asset prices.

In sum, it seems that the relationship between the aggregate economy and the real estate markets can be quite complicated and it takes more than a single theory to provide the full picture. In light of the development of the literature, this chapter attempts to provide a more updated review on the Hong Kong experience during the financial crises and hopefully it can shed light on the future development of the related theoretical literature and enable us to deepen our understanding. It will be organized as follows. It first reviews the historical background of the Hong Kong economy, and then recalls the incident of currency attack in 1998. To enrich the understanding of the housing market, discussions on land sale procedures and mortgage market will be followed. Next, it compares the performance of housing market during the AFC and the GFC, using the event study techniques. Conclusions will be made at the end of this chapter.

\section{Background}

It may be instructive to begin this chapter with some historical background of Hong Kong. The development history of Hong Kong can be traced since $19^{\text {th }}$ century. At that time, Hong Kong was a fish village in the $19^{\text {th }}$ century. A wide and deep Victoria Harbor was probably the only natural resource. In 1842, Qing Dynasty was defeated in the First Opium War, and Hong Kong Island was ceded to Britain under the Treaty of Peking. In 1860, Qing Dynasty was again defeated in the Second Opium War. The Kowloon Peninsula and Stonecutters Island were 
ceded to the British under the Convention of Peking. Finally in 1898, the British obtained a 99year lease of the New Territories under the terms of the Convention for the Extension of Hong Kong Territory. Since then, the fate of Hong Kong was totally changed.

To utilize Hong Kong's geographical advantage, the British government turned Hong Kong to an "entry port" in early $20^{\text {th }}$ century. The trades between South China and foreign countries had to pass via Hong Kong. In 1949, People's Republic of China established, so many refugees and corporations came to Hong Kong to avoid persecution. The sudden increase in labor created favorable conditions for Hong Kong to develop its textile and manufacturing industries. With the open policy of mainland China in 1979, and the increasing labor cost in Hong Kong, manufacturing companies moved their operations to China in waves. Hong Kong's role in manufacturing industry eventually declined, and it had to reposition as a service center. In 1980 , service industry constituted $68 \%$ of GDP, and it increased to $86.5 \%$ in 2000 . Its free market policies, low corruption rate, highly educated and productive labor force, and strong financial infrastructures have attracted a lot of funds flowing into Hong Kong. Nowadays, Hong Kong keens on developing as an international financial center. And through its rapid sectoral changes, Hong Kong achieves a significant economic growth. Starting from HK\$26,094 of per capita GDP [expressed in constant dollars, 2008 level] in 1961, it increases 9.2 times to HK\$240,096 in 2008 [Exhibit 7.1]. Population also exhibits continuous growth. It starts from $3,168,000$ in mid 1961 and reaches to $6,988,900$ in the year-end of 2008 [Exhibit 7.2]. The continuing growth in population and the per capita income naturally lead to an increasing demand for housing. In fact, the real housing price index in Hong Kong has increased from 100 in 1979 to 162.5 in 2008, despite some downturns in between. As long as the land resource in Hong Kong is scarce, we will expect a general increase in the real housing prices [Exhibit 7.3]. Exhibit 7.3 also shows that the housing price drop after the AFC is so much that even when the GFC happens in 2008, the (average) level of housing price in Hong Kong has not recovered to the level before AFC (more systematic comparison will be provided in later section). 
Exhibit 7.1 Time plot of Per Capita GDP [expressed in constant (2008) dollars]

[Exhibit 7.1 about here]

Source: Census and Statistics Department

Exhibit 7.2 Time plot of population

[Exhibit 7.2 about here]

Source: Census and Statistics Department

Note: The figures from 1961 to 1995 are obtained by "extended de facto" method, while the figures from 1996 onwards are obtained by "resident population" method.

Exhibit 7.3 Time plot of real housing price index (base year: December 1979)

[Exhibit 7.3 about here]

Source: Rating and Valuation Department 


\section{Currency attack (1998) in Hong Kong}

Expecting more capital coming from China, Hong Kong experienced a sharp increase in the real estate prices during the first half of 1997, just before the "handover."2 Now looking through a rear-mirror, an asset bubble was created at that time. Some numerical figures can shed light on this point: From January 1990 to March 1997, the real wage index only increased by $3.8 \%$ [Exhibit 7.4], but the inflation rate was $80.0 \%$. Also, the real aggregate GDP, real Hang Seng Index and real housing price increased by $32.6 \%, 153.1 \%$ and $101.4 \%$ respectively. These figures reveal a few facts. First, the income distribution has become more unequal (the aggregate GDP increases are much higher than that of the real wage). Clearly, those who can take advantage of the economic growth of China (such as lawyers, accountants, entrepreneurs) would have their incomes growing much faster than those who provide routine labor in Hong Kong. Second, the asset prices (stock and housing) become more expensive. In fact, the ratio of the housing price index relative to wage index ratio doubles from 100 in 1982 to 200 at the housing price peak in 1997 [Exhibit 7.5]. If those who earn higher income also save more, which seems to be true in many countries, then the wealth inequality between the high income group and the low income group has also increased. ${ }^{3}$

The real prices of both office and retail property also increased significantly before the AFC. Both of them increase from 100 in 1986 to more than 350 before the AFC. ${ }^{4}$ It led to an increase in the business operating cost within that period, and translated into higher selling prices of the finished products. [Exhibit 7.6]. The competitive power was then weakened. To regain its competitive power, obviously Hong Kong had to reduce the production cost by either devaluing the currency or, perhaps painfully, devaluing the real estate prices.

(As it is well known, the importance of the manufacturing industry diminished in Hong Kong since 1980 [Exhibit 7.7]. The real price of factory therefore drops since 1993 (around 250)

\footnotetext{
2 Among others, see Chow et al (2002) on this point.

${ }^{3}$ Unfortunately, the government does not provide data on the wealth inequality in Hong Kong.

${ }^{4}$ Interestingly, before the GFC in 2008 occurs, the office price in real terms is restored to the level of 1997, before the AFC. For the case of real retail property, it even surpasses its 1997 value before the GFC.
} 
to 2003 (around 70). ${ }^{5}$ Recently, the high price of office and retail properties motivates more redevelopment. As a result, the real price of factory climbs back to around 200 before the GFC.)

Speculators understood the conditions of Hong Kong, and they were trying to make money by taking "Double Market Play" ${ }^{6}$ : They simultaneously sold short Hong Kong dollars, both spot and forward, on the foreign exchange market and shorted Hong Kong stocks on both the spot and futures markets. If the Hong Kong dollar peg was given up, speculators would make substantial amounts of money from the foreign exchange market; if the interest rate rose, they could also make profits from the securities market. It seemed that with this strategy the speculators would make a huge profit at the expense of the Hong Kong residents.

Exhibit 7.4 Time plot of real wage index (base: September 1992)

[Exhibit 7.4 about here]

Source: Census and Statistics Department

Exhibit 7.5 Time plot of housing price index relative to wage index (rebased as 100 at March 1982)

[Exhibit 7.5 about here]

Source: Rating and Valuation Department (for housing price series) and Census and Statistics Department (for wage index series)

\footnotetext{
${ }^{5}$ See Leung, Wei and Wong (2006) for more details. 6 See Goodhart and Dai (2003) for more details.
} 
Exhibit 7.6 Time Plot of the Quarterly Real Estate Price Index, Rebased at March 1986, in Real Terms

[Exhibit 7.6 about here]

Source: Rating and Valuation Department

Exhibit 7.7 Contributions of Manufacturing and Services Industry to Gross Domestic Product

[Exhibit 7.7 about here]

Source: Census and Statistics Department

Doubtlessly, it was challenging for the government officials to defend from such systematic speculation. First, they had to protect the currency from devaluation. Linked exchange rate system had been enforced for more than 15 years, and it was widely accepted by the citizens. If the government abandoned this system, it should be a shock to the economy. In the worst scenario, people would lose the confidence about the domestic currency. Together with a free capital control in Hong Kong and instable Asian financial markets, further speculation on the currency was very likely, and the currency may be over-devalued. Second, they had to prevent the financial market from collapse. Financial industry is one of the most important "economic pillars" in Hong Kong. Sudden fall in asset value would cause the problem of negative equity. It would then affect the banks as the loans can never be repaid. Local economy would severely be affected.

On 14 August 1998, the Hong Kong Monetary Authority (HKMA) unexpectedly used the official reserves to purchase stocks aiming that the speculators will not profit from market 
manipulation. The intervention process stopped at 28 August 1998. After that, the increased stability in the financial market attracted the inflow of funds and the Hang Seng Index caught up to above 10,000 points in October 1998. Moreover, in order to dispose the shares with minimal disruption to the market, the Tracker Fund of Hong Kong was launched in November 1999. It replicates the performance of Hang Seng Index, so investors can gain immediate diversification and exposure to the largest stocks in Hong Kong market.

Definitely, the intervention taken in August 1998 would bring some concerns about the "positive non-intervention" policy adopted since 1971. Donald Tsang, the Financial Secretary of Hong Kong, explained that if the government did not take interventions, the stock market would fall between 2,000 and 3,000 points and the interest rate would rise by $50 \%$. The value of the asset would fall below the fundamental value and the market crash would trigger serious actions by other investors. The local economy will then be sent to recession quickly ${ }^{7}$. Therefore, the government had to intervene the market directly in order to restore the confidence of the public.

Together with the intervention of financial market, HKMA took seven measures on 5 September 1998 to strengthen the currency board arrangements in Hong Kong ${ }^{8}$ :

1. To demonstrate the Government's commitment to the linked exchange rate system, HKMA provides a clear undertaking to all licensed banks in Hong Kong to convert Hong Kong dollars in their clearing accounts into US dollars at the fixed exchange rate of HK\$7.75 to US\$1.

2. As the improved efficiency of the interbank payment system has facilitated liquidity management of licensed banks, the bid rate of the Liquidity Adjustment Facility is removed.

7 For more details, see Goodhart and Dai (2003), Leung, Wong and Cheung (2007), Leung, Cheung and Tang (2009), among others.

8 Hong Kong Monetary Authority, 5 September 1998. Strengthening of Currency Board Arrangements in Hong Kong, Press Release. Details are available at:

http://www.info.gov.hk/hkma/eng/public/qb9811/pdf/qbfa02.pdf 
3. Replacing the Liquidity Adjustment Facility by a Discount Window with a base rate. The base rate will be responsive to capital flows and is determined by HKMA from time to time so that excessive and destabilizing interest rate volatility is dampened.

4. By removing the restriction on repeated borrowing in respect of the provision of overnight Hong Kong dollar liquidity through repo transactions using Exchange Fund Bill and Notes, it can make the monetary system less susceptible to manipulation and dampen excessive interest rate volatility.

5. To ensure that all new Exchange Fund papers are backed by foreign currency reserves, it will only be issued when there is an inflow of funds.

6. Introducing a schedule of discount rates applicable for different percentage thresholds of holdings of Exchange Fund paper by licensed banks for the purpose of assessing the Discount Window.

7. Retaining the restriction on repeated borrowing in respect of repo transactions involving debt securities other than Exchange Fund paper.

On 14 October 1998, Joseph Yam, Chief Executive of HKMA, delivered a speech ${ }^{9}$ that the officials were taking difficult decisions to protect the overall public interest. He mentioned that "the HKMA is against market manipulation, specifically the manipulation of the currency market, taking advantage of the passiveness under the discipline of the rule-based currency board arrangements, to produce interest rates with a view sending the stock market into a nosedive and benefiting from a short position in stock index futures." He concluded that after the government intervened the market, speculators suffered considerable losses in the short position in currency market and stock market futures, and there had been no indication of further market manipulation since August 1998. HKMA was successful to defeat speculators from attacking Hong Kong monetary and financial systems. Nevertheless, there is no free lunch. The defense of the peg exchange rate comes with a price, which includes a significant drop in

9 Yam, J., 14 October 1998. Defending Hong Kong's Monetary Stability. Speech at TDC Networking Luncheon, Singapore. Details are available at:

http://www.info.gov.hk/hkma/eng/speeches/speechs/joseph/speech 141098b.htm 
the real estate value. Before we provide more details on that, we would first explain why the real estate value in Hong Kong is high in the first place.

As a comparison, during the GFC in 2008 , the source of the shock is the North American, and then Europe. There is no significant speculation against the Hong Kong dollars. On the contrary, there is an inflow of capital. Thus, neither the Hong Kong Monetary Authority needs to raise the interest rate, nor the Hong Kong Government uses the fiscal reserve to intervene the stock market. The asset market is mainly driven by the market force during the GFC. ${ }^{10}$

\section{$\underline{\text { Land size and its sale procedures }}$}

It is not an over-statement that the rise and fall of the real estate value in Hong Kong is tied to a sequence of historical events. When Hong Kong was the British colony in 1898, the boundary of Hong Kong had already fixed with a size of $1104 \mathrm{~km}^{2}$. With the scarce land resources and growing population, we are pleased that the "needs for accommodation" are by and large satisfied. As shown in Exhibit 7.8, there is a housing unit for each household on average. On the contrary, more attention is paid to the "high land price policy" maintained by the Government. As the government owns all the land and sells it to the property developer at a high price, the government is able to maintain low tax rate in income with fiscal balance over years. On the other hand, profit-maximizing property developers will sell their properties at an even higher price to the buyers.

Before April 1999, the Government adopted a regular sale of land, which provided a stable source of income to Government. The Government can then use the funds to provide free education, maintain high standard of medical services and create jobs. In the fiscal year $1996 / 97$, the land sale revenue accounted for $8.63 \%$ of the total government revenue. In April 1999, the Chief Executive, Tung Chee-Hwa, introduced the application list system. Under this system, the Government published a list of land available for sale upon application. Property developers who are interested in sites need to state the minimum amount they are willing to

\footnotetext{
${ }^{10}$ See Yiu et al (2010) for more details.
} 
pay in the application. If the Government approves it, the land will be offered for sale at a public auction. In January 2004, the "regular sale of land system" was completely replaced by the "application list system"11. Recently, there were fewer pieces of land sold through the application list system. Government can no longer rely on this source of income.

In fact, "high land price policy" was criticized by citizens. Since the private housing is unaffordable to most of the people, it gives pressure to the Government to build more public houses to satisfy their living needs. For those who buy a house, mortgages already share a large portion of the total income. Hence, the investments in real estates may become burdens under unfavorable economic conditions. A typical example is the Asian Financial Crisis. During this period, the assets declined in value, people lost their jobs yet they still had to repay the mortgages.

In addition, the government and property developers might have incentives to jointly push up the house prices. Government can control the land supply by fixing the number of land released for application. And since the Hong Kong housing market is dominated by a small number of developers, they could decrease the total new supply and push up the unit price at the same time. ${ }^{12}$ Therefore, it seems that the land policies work unfavorably to the citizens, and hence there are more voices asking for the replacements of the policies.

Exhibit 7.8 Time plot of total housing units relative to total households

[Exhibit 7.8 about here]

Source: CEIC (for total housing units' series) and Census and Statistics Department (for total households' series)

11 Even though the Government took an active role to sell the land located at Ho Man Tin in 8 June 2010, there is no further evidence that the current land sale arrangement will be replaced shortly.

12 For more discussion on the oligopolistic structure of the Hong Kong housing market, see Renaud, Pretorius and Pasadilla (1997), among others. 


\section{Mortgage market}

Given the high housing price, it is unlikely for a typical household to purchase the home with cash. Making mortgage loan seems to be the only alternative. In Hong Kong, making mortgage loan is regarded as a low-risk business, because there is an upward trend in the real estate prices and a low default rate. Financial institutions are willing to offer the mortgage plans with lower interest rate to the customers, and as a result, there is a large increase in the mortgage loan. For example, between July 1984 and September 1993, the monthly mortgage deeds received by the Land Registry of the Hong Kong Government, which includes both mortgage re-finance cases and the newly issued mortgage cases, rose sharply from 4,525 cases to 22,055 cases [Exhibit 7.9]. However, with the heavy reliance of mortgage business, there are problems underlying. The first one is a typical maturity mismatch problem of financial intermediations. The assets of the financial institutions are usually long-term, while the liabilities are short-term. Financial institutions depend on foreign capital to fund all the loans. When the foreign short term capital (or so-called "hot money") withdraws from the Hong Kong market, there is a danger that the Hong Kong banking system is unable to provide enough funding for the credit. Since the loans to mortgage are long-term (10 to 20 years) and in a sense pre-committed, the banking system will be forced to reduce other loans that are relatively short-term, including loans to small and medium business, which it can result in some kind of "credit crunch." The economy becomes vulnerable to the external funding shocks. Exhibit 7.10 is consistent with this hypothesis. Notice that the total amount of loan actually drops from more than 4 trillion Hong Kong dollars (1997) to about 2 trillion Hong Kong dollars (2002). At the same time, the ratio of residential loans to the total loans increases from slightly above $6 \%$ to more than $30 \%$. The banking sector as a whole may have over-exposure to the housing loans.

Clearly, similar problems have been experienced by advanced economies such as the United States. With the examples of Fannie Mae and Freddie Mac in the mind of some regulators, the Hong Kong Mortgage Corporation Limited (HKMC) was established in March 1997. This Corporation is wholly owned by the government through the Exchange Fund. Its 
Guaranteed Mortgage-Backed Pass-Through Programme aims to provide an efficient and costeffective way for the banks to convert their illiquid residential mortgage loans into liquid mortgage-backed securities (MBS). In principle, the programme can improve the stability of the banking and monetary system. In practice, however, none of the major banks join this program as they perceive that the house value would continue to have an upward trend and there would be a continuing inflow of capital from China and other countries. It leaves the Hong Kong banking system of vulnerable to potential exchange rate shock and interest rate shock. ${ }^{13}$ In that sense, the Hong Kong economy as a whole has not learnt as much as they should from the AFC. And if the Hong Kong economy fates better than the GFC, it seems that the direction of capital flow plays a more important role than institutional changes.

Exhibit 7.9 Time Plot of Monthly Issued Mortgages

[Exhibit 7.9 about here]

Source: CEIC

Exhibit 7.10 Ratio of Residential loans to the total loans in all financial institutions

[Exhibit 7.10 about here]

Source: CEIC

13 The failure to securitize the mortgage debts as well as to "dollarize" the foreign debt seems to be common across Asian countries during the AFC, and may contribute a significant part in the large impact of the AFC. Among others, see Choi and Cook (2004), Chue and Cook (2008) for more details. 


\section{Performance of Housing Market in Asian Financial Crisis (AFC)}

As mentioned previously, Hong Kong has been developing its service industry since 1980 . Between 1981 and 1992, its real GDP [in chained (2008) dollars] nearly doubled from HK\$121,915 million to HK\$238,107 million, while the unemployment rate dropped from 3.1\% to 2.0\% [Exhibit 7.11]. The wealth started to accumulate among households, and that leads to an increase in house price. The increase in house price relaxes the collateral constraints of those who originally live in small houses. As in the model of Ortalo-Magne and Rady (2006), those households now trade-up (i.e. sell the small units and buy bigger ones), and we would expect an increase in the number of mortgage loans and an even higher house price in the economy.

In the first half of 1997, the asset bubble was inflated to the extreme. Specifically, real Hang Seng Index reached a peak of 14,677 points in July 1997 [Exhibit 7.12]. On the other hand, the housing price index stayed at the peak in the second quarter of 1997 [Exhibit 7.6]. The increasing trend of the asset markets encouraged more people involving in them. ${ }^{14}$ In August 1997, the turnover value (in real terms) and volume in stock market were HK\$569,774 million and 312,900 million shares respectively [Exhibit 7.12], attaining the historical highest point; similarly in the housing market, 27,611 registered mortgage cases were recorded [Exhibit 7.9].

Such a good market sentiment was maintained until the Financial Crisis attacked Hong Kong in the late 1997. The interest rate was raised by the HKMA to defend the peg exchange rate. After that, Hong Kong experienced a recession: Within a year, the real stock market index dropped significantly by more than 50\%; the housing prices declined by $40 \%$; the unemployment rate rose by $3 \%$; and the real GDP declined by $9 \%$. As a consequence, the wealth of the existing homeowners dramatically reduced. They had to face the problem of negative equity, where the amount of outstanding mortgage loan was greater than the value of asset. For some homeowners, they decided to continue the repayment of mortgage loan, and hoped that the housing price would rebound in the future. For others, they may defer the mortgage payment, sell the houses at a discount, or declare bankruptcy. As shown in the

14 There are many justifications for "trend-chasing." Among others, see Orosel (1998) for a rational foundation for trend-chasing behavior in the financial market. 
Exhibit 7.13, both the real amount of outstanding loans and delinquency ratio increased during the period of 1998 to 2001.

Exhibit 7.11 Time Plot of Real GDP [in chained (2008) dollars] and Unemployment Rate

[Exhibit 7.11 about here]

Source: Census and Statistics Department

Exhibit 7.12 Time Plot of Real Hang Seng Index (base year: July 1964) and Its Turnover

[Exhibit 7.12 about here]

Source: Hong Kong Exchanges and Clearing Limited

Exhibit 7.13 Time plot of Real Outstanding Mortgage Loans and Delinquency Ratio

[Exhibit 7.13 about here]

Source: CEIC 


\section{Event study}

The Asian Financial Crisis (AFC) was a very painful experience to Hong Kong. Before the AFC, the positive expectation in Hong Kong was so extreme that some people quit the jobs to "work as full-time speculators." Thus, when the AFC hits Hong Kong, many people were caught in surprises. Even the government official admits that. In the Hong Kong Year Book 1998, Donald Tsang, the Financial Secretary at that time, wrote: "Now that we can look back on it, 1998 was surely a year to remember. Many of the lessons were far from pleasant but, so long as we learn from them, we can only grow and improve." ${ }^{15}$ In fact, the government has imposed many policy measures to guard against another financial crisis. And perhaps an equally important fact is that the investors in Hong Kong change their expectations since then. In December 2009, the same Donald Tsang, now the Chief Executive, comments that, "Financial Tsunami is different from Asian Financial Crisis, where it starts from United States of America and affects globally. To defend us from the attack of the crisis, one basic strategy is to have a certain level of foreign reserves. Countries or nations cannot solely depend on financial industry, but have to develop other industries." ${ }^{16}$ On top of the institutional changes that the Hong Kong government has implemented after the AFC ("learning effect"), the emergence of China and its close relationship with Hong Kong could also reduce the impact of the GFC to Hong Kong.

To assess whether Hong Kong does behave differently, this section will employ event study graphs for illustration. The choice of the frequency of data matters. For one thing, most economic variables would not have high frequency data. On the other hand, if the frequency is chosen to be annual, some of the impact of the crisis will be covered as the impact period is "averaged out" by subsequent period. ${ }^{17}$ As a compromise, we choose the quarterly data, and monthly when it is available. We can get most of the macroeconomic time series from the Hong Kong Government website, with a few exceptions, such as the wage index. Therefore, we use the IMF data for the wage index, and it is in quarterly frequency. To facilitate the comparison, all the variables are rebased as 100 at the time of AFC (December or fourth quarter of 1997)

15 Hong Kong Yearbook 1998. Details are available at: http://www.yearbook.gov.hk/1998

16 Commercial Radio, 29 December 2009. Details are available at: http://881903.com

${ }^{17}$ The "time aggregation bias" has been studied by Christiano and Eichenbaum (1987), Christiano, Eichenbaum and Marshall (1991). 
and GFC (September or third quarter of 2008). Pre- and post-crisis performances can then be easily observed.

Let's start with the asset markets. As shown in Exhibit 7.14a, real housing prices dropped by $40 \%$ after 10 months of AFC, and it still didn't recover after 24 months. Compared to the case of Financial Tsunami, housing price took a shorter period (11 months) to go back to pre-crisis level. The situation for real office price is similar [Exhibit 7.14b]. It takes a much shorter time to recover during the GFC than the AFC. For the real retail property price, it dropped significantly during the AFC [Exhibit 7.14c]. During the GFC, however, it has dropped shortly but then actually surpassed the level before the GFC! It is quite possible that the continuing economic growth in China brings many tourist-shoppers to Hong Kong. Their spending capacity is strong enough that the retail property price does not suffer any loss after adjusting for inflation. Similarly, in the stock market, Hang Seng Index dropped dramatically at the happening of the crisis. The effect of AFC is more long-lasting, in which Hang Seng Index took about 15 months to reach the pre-crisis level again [Exhibit 7.14d]. The data seems to be consistent with the notion that Hong Kong investors are better prepared this time (for instance, through better risk management through different financial instruments), and hence the asset markets took a shorter period to recover.

For the economy as a whole, its activity was dampened with the attack of financial crises. As shown in Exhibit 7.14e, the real GDP declined more than $10 \%$ after the two financial crises. However, real GDP did not recover after 7 quarters of AFC; while it took 5 quarters to recover after the GFC. The real wage index displayed in Exhibit 7.14f is consistent with the case of GDP. During the AFC, after adjusting for the inflation, the wage index has dropped more than $30 \%$ after 2 quarters and stays stagnated for more than a year. During the GFC, on the other hand, the real wage is basically unchanged. For other macroeconomic indicators, such as investment and consumption, their performances under AFC were similar. People were conservative in spending and hence the values only recovered slowly after two years of AFC [Exhibits 7.14g and 7.14h]. The employment market seemed to be badly affected by AFC. The unemployment rate was 2.5 times more than the pre-crisis level and there was no tendency for it to fall after 8 
quarters. In contrast, the Hong Kong labor market seems to be much less affected during the recent GFC [Exhibit 7.14i]. The continuing economic downturn and inappropriate housing policies during the AFC were two of the main reasons for Tung Chee-Hwa to step down in 10 March 2005.

Because of a fall in income during poor economic conditions, housing market was seriously affected. People were cautious about purchasing houses and the real value of housing transactions in secondary market did not get improved after the crisis. On the contrary, the secondary market transaction in Hong Kong actually increases since the outbreak of the Global Financial Crisis. Part of the reason may be due to the continuous economic growth of China and the willingness for the China investors to diversify their portfolio in Hong Kong housing market [Exhibit 7.14j]. ${ }^{18}$ For the outstanding mortgage loans, it rose by $15 \%$ after 20 months of AFC. At that time, the real estate developers provided some "secondary mortgage" to buyers in order to liquidate their inventory (i.e. the housing units ready for sale). Also, the government has launched many policies to encourage people to participate in different "subsidized ownership schemes" as a way to "stabilize" the housing market. As a result, the total amount of mortgage can actually increase when the total value of secondary market trading decreases. On the other hand, these policies are no longer there this time. The outstanding mortgage loans remain more or less the same after the recent financial Tsunami [Exhibit 7.14k]. In addition, the ratio of the residential loans relative to the total rose by $60 \%$ after 2 years of AFC, while its ratio stabilizes after financial tsunami, which suggests that financial institutions are more prudent in making loans [Exhibit 7.14l].

In summary, the lessons that AFC brought to us are memorable. After that, through a series of rectifications and improvements, the housing market became better-behaved. Banks are better in managing their loan portfolio, as the proportion of residential loans is kept stable after the GFC. In addition, relative to GDP, the transactions in the secondary housing market were very active after 2 quarters of the GFC [Exhibit 7.14m], while the outstanding mortgage

\footnotetext{
${ }^{18}$ See Leung and Tang (2010) for more discussion on that.
} 
loans were much smaller than that in AFC [Exhibit 7.14n]. All these suggest that the economy as a whole may be less vulnerable to another financial crisis.

Exhibit 7.14a Event Study - Real Housing Price

[Exhibit 7.14a about here]

Source: Rating and Valuation Department, Hong Kong Government

Exhibit 7.14b Event Study - Real Office Price

[Exhibit 7.14b about here]

Source: Rating and Valuation Department, Hong Kong Government

Exhibit 7.14c Event Study - Real Retail Property Price

[Exhibit 7.14c about here]

Source: Rating and Valuation Department, Hong Kong Government

Exhibit 7.14d Event Study - Real Hang Seng Index

[Exhibit 7.14d about here]

Source: Hong Kong Exchanges and Clearing Limited 
Exhibit 7.14e Event Study - Real GDP

[Exhibit 7.14e about here]

Source: Census and Statistics Department

Exhibit 7.14f Event Study - Real Wage Index

[Exhibit 7.14f about here]

Source: IMF

Exhibit 7.14g Event Study - Real Investment

[Exhibit 7.14g about here]

Source: Census and Statistics Department

Exhibit 7.14h Event Study - Real Consumption

[Exhibit 7.14h about here]

Source: Census and Statistics Department

Exhibit 7.14i Event Study - Unemployment Rate

[Exhibit 7.14i about here]

Source: Census and Statistics Department 
Exhibit 7.14j Event study - Real Transaction Value in Secondary Housing Market

[Exhibit 7.14j about here]

Source: CEIC

Exhibit 7.14k Event Study - Real Outstanding Mortgage Loans

[Exhibit 7.14k about here]

Source: CEIC

Exhibit 7.14l Event study - Ratio of Residential loans to the total loans in all financial institutions

[Exhibit 7.14l about here]

Source: CEIC

Exhibit 7.14m Event study - Ratio of the value of trading in secondary housing market relative to the GDP

[Exhibit 7.14m about here]

Source: CEIC

Exhibit 7.14n Event study - Ratio of the value of outstanding mortgage loans relative to the GDP [Exhibit 7.14n about here]

Source: CEIC 


\section{$\underline{\text { Conclusion }}$}

If home ownership is a dream for the working class, then the continuous economic growth in Hong Kong between the 1960s and 1990s has made this dream apparently tangible. People work hard for the house with rising wages. Even though the house price rises even faster, it confirms the "conventional wisdom" that house price can only increase. This gives people even more incentives for home ownership, perhaps more than one home for each household. The Asian Financial Crisis (AFC) changes all these perceptions and behaviors. Households experience negative equity and since mortgage loan in Hong Kong is recourse by nature, people are "trapped" in their "under-water houses." At the same time, the banking sector face the external shock of the AFC and find herself being over-exposed to the risk in the residential loan sector. The government also experienced fiscal deficit, which rarely happens since the 1970s. The whole Hong Kong was under in great distress.

Lessons are painfully learnt and policy measures are implemented. For instance, to improve the market efficiency, Hong Kong Mortgage Corporation was established in 1997. This gives an additional option for individual bank. In addition, some government interventions and strengthening measures were taken during AFC, including using the fiscal reserve to purchase stock in the financial market, and imposing more stringent rules on short-term capital flow ("hot money"). All these seem to contribute to the stabilization of the market.

Our event study seems to suggest that the Hong Kong economy does behave differently during the AFC and the recent GFC. In particular, it seems that the adverse effect of external shocks on different aggregate economic variables are much smaller, and takes a much shorter time to have their effects die out. It can be due to the government policy (the "learning effect"). It may also be due to "the China factor." Of course, it can be argued that the learning effect is so significant that the Chinese investors perceive the Hong Kong market has become "safer" than before and hence are more willing to invest in Hong Kong. It will take another careful empirical study to investigate the relationship between the learning effect and the China factor. An alternative explanation is related to a possible change in the perception of the investors. The AFC experience clearly illustrates that the housing price can decrease, and decrease 
dramatically. This may lead to a revision of the investment strategy for the local investors. Econometrically, it would mean a structural change in the system. Recent research such as Leung, Wong and Cheung (2007), Leung, Cheung and Tang (2009), among others, have taken some preliminary steps along this direction. Clearly, more research efforts are needed to gain a better understanding for how the real estate market, financial crisis and the general economic structure of an economy interact with one another. 


\section{References}

1. Brown, G. W., and M. T. Cliff, 2004. Investor Sentiment and the Near-term Stock Market. Journal of Empirical Finance, 11, 1-27.

2. Brown, G. W., and M. T. Cliff, 2005. Investor Sentiment and Asset Valuation. Journal of Business, 78(2), 405-440.

3. Canbas, S., and S. Y. Kandir, 2009. Investor Sentiment and Stock Returns: Evidence from Turkey. Emerging Markets Finance and Trade, 45(4), 36-52.

4. Case, K. E., J. M. Quigley, and R. J. Shiller, 2005. Comparing Wealth Effects: The Stock Market Versus the Housing Market. Advances in Macroeconomics, 5(1), 1-32.

5. Census and Statistics Department, http://censtatd.gov.hk .

6. Chan, K.; P. Yip, J. Au and D. Lee, 2005, Charcoal-burning suicide in post-transition Hong Kong, British Journal of Psychiatry, 186, 67-73.

7. Chang, S. S.; D. Gunnell, J. Sterne, T. H. Lu and A. T.A. Cheng, 2009, Was the economic crisis 1997-1998 responsible for rising suicide rates in East/Southeast Asia? A timetrend analysis for Japan, Hong Kong, South Korea, Taiwan, Singapore and Thailand, Social Science and Medicine, 68(7), 1322-1331.

8. Chen, N. K., S. S. Chen and Y. H. Chou, 2010, House prices, collateral constraint, and the asymmetric effect on consumption, Journal of Housing Economics, 19, 26-37.

9. Chen, N. K. and C. K. Y. Leung, 2008, Asset Price Spillover, Collateral and Crises: with an Application to Property Market Policy, Journal of Real Estate Finance and Economics, 37, 351-385.

10. Choi, W. G. and D. Cook, 2004, Liability Dollarization and the Bank Balance Sheet Channel, Journal of International Economics, 64(2), 247-75.

11. Chow, Y. F., C. K. Y. Leung, N. Wong, E. H. F. Cheng and W. H. Yan, 2002, Hong Kong Real Estate Market: Facts and Policies, Hong Kong: Ming Pao Publisher (in Chinese).

12. Christian, L. and M. Eichenbaum, 1987, Temporal Aggregation and Structural Inference in Macroeconomics, Carnegie-Rochester Conference Series on Public Policy, 26, 63-130.

13. Christian, L., M. Eichenbaum and D. Marshall, 1991, The Permanent Income Hypothesis Revisited," Econometrica, 59, 397-424.

14. Chue, T. K. and D. Cook, 2008, Sudden Stops and Liability Dollarization: Evidence from Asia's Financial Intermediaries, Pacific-Basin Finance Journal, 16(4), 436-52.

15. Commercial Radio, http://881903.com

16. Fu, Y., 2000. Hong Kong: Overcoming Financial Risks of Growing Real Estate Credit, in Asia's Financial Crisis and the Role of Real Estate, eds., Koichi Mera and Bertrand Renaud, New York: M. E. Sharpe, 139-158.

17. Goodhart, C. and L. Dai, 2003. Intervention to Save Hong Kong, Oxford: Oxford University Press. 
18. Gyourko, J. and D. Keim, 1992. What Does the Stock Market Tell Us About Real Estate Returns? Journal of the American Real Estate and Urban Economics Association, 20, 457-485.

19. Haldane, A. G., Executive Director, Financial Stability, Bank of England, 8 May 2009. Small Lessons From a Big Crisis.

20. Haldane, A. G., Executive Director, Financial Stability, Bank of England, 27 January 2010. The Debt Hangover.

21. He, L. T., F. C. N. Myer and J. R. Webb, 1996. The Sensitivity of Bank Stock Returns to Real Estate. Journal of Real Estate Finance and Economics, 12(2), 203-220.

22. Ho, L.S. and G. Wong, 2006. Privatization of public housing: did it cause the 1998 recession in Hong Kong? Contemporary Economic Policy, 24 (2), 262-273.

23. Ho, L.S. and G. Wong, 2008. Nexus between housing and the macro economy: the Hong Kong case. Pacific Economic Review, 13 (2), 223-239.

24. Ho, L.S. and G. Wong, 2009. The first step on the housing ladder: A natural experiment in Hong Kong, Journal of Housing Economics, 18, 59-67.

25. Ho, L.S., Y. Ma, and D. Haurin, 2008. Domino effects within a housing market: the transmission of house price changes across quality tiers. Journal of Real Estate Finance and Economics, 37 (4), 299-316.

26. Hoesli, M., and W. Camilo, 2007. Securitized Real Estate and Its Link with Financial Assets and Real Estate: An International Analysis. Journal of Real Estate Literature, 15(1), 59-84.

27. Hong Kong Monetary Authority, 5 September 1998. Strengthening of Currency Board Arrangements in Hong Kong.

28. Hong Kong Mortgage Corporation, Guaranteed Mortgage-Backed Pass-Through Programme, http://www.hkmc.com.hk

29. Hong Kong Yearbook 1998, http://www.yearbook.gov.hk/1998

30. Housing Department, http://www.housingauthoriy.gov.hk

31. Jin, Y.; C. K. Y. Leung and Z. Zeng, 2010, Real Estate, the External Finance Premium and Business Investment: A Quantitative Dynamic General Equilibrium Analysis, forthcoming in Real Estate Economics.

32. Koop, G., M. H. Pesaran and S. M. Potter, 1996. Impulse Response Analysis in Nonlinear Multivariate Models. Journal of Econometrics, 74, 119-147.

33. Kothari, S. P., and J. B. Warner, 2007. Econometrics of Event Studies, Handbook of Corporate Finance, Volume 1, Elsevier.

34. Lands Department, http://www.landsd.gov.hk

35. Leeper, E. M., C. A. Sims, and T. Zha, 1996. What Does Monetary Policy Do? Brookings Papers on Economic Activity, No. 2, 1-78.

36. Leung, C. K. Y. and N. K. Chen, 2006. Intrinsic cycles of land price: a simple model, Journal of Real Estate Research, 28(3), 293-320. 
37. Leung, C. K. Y. and N. K. Chen, 2010. Stock Price Volatility, Negative Auto-correlation and consumption-wealth ratio: the case of constant fundamentals, Pacific Economic Review, 15(2), 224-245.

38. Leung, C. K. Y., P. W. Y. Cheung and E. C. H. Tang, 2009. Financial Crisis and the Comovements of Housing Sub-markets: Do Relationships Change After a Crisis? Working Paper.

39. Leung, C. K. Y. and D. Feng, 2005. What drives the property price-trading volume correlation: evidence from a commercial real estate market, Journal of Real Estate Finance and Economics, 31(2), 241-255.

40. Leung, C. K. Y., G. C. Lau and Y. C. F. Leong, 2002. Testing Alternative theories of the property price-trading volume correlation, Journal of Real estate Research, 23 (3), 253263.

41. Leung, C. K. Y. and E. C. H. Tang, 2010. Speculating China economic growth through Hong Kong? Evidence from the stock market IPO and real estate markets, City University of Hong Kong, mimeo.

42. Leung, C. K. Y., P. Wei and S. K. Wong, 2006. Are the markets for factories and offices integrated? Evidence from Hong Kong, International Real Estate Review, 9, 62-94.

43. Leung, C. K. Y., S. K. Wong and P. W. Y. Cheung, 2007. On the Stability of the Implicit Prices of Housing Attributes: A Dynamic Theory and some Evidence. International Real Estate Review, 10(2), 65-91.

44. Liu, C. H., D. J. Hartzell, W. Greig and T. V. Grissom, 1990. The Integration of the Real Estate Market and the Stock Market: Some Preliminary Evidence. Journal of Real Estate Finance and Economics, 3(3), 261-282.

45. Lutkepohl, H., 2005. New Introduction to Multiple Time Series Analysis, New York: Springer.

46. Ming Pao, http://www.mingpao.com.

47. Okunev, J., P. Wilson and R. Zurbruegg, 2000. The Causal Relationship between Real Estate and Stock Markets. Journal of Real Estate Finance and Economics, 21(3), 251-261.

48. Orosel, G. O., 1998, Participation costs, trend chasing, and volatility of stock prices, Review of Financial Studies, 11, 521-557.

49. Ortalo-Magne, F. and S. Rady (2006), Housing Market Dynamics: On the Contribution of Income Shocks and Credit Constraints, Review of Economic Studies, 73, 459-485.

50. Pesaran, M. H. and Y. Shin, 1998. Generalized Impulse Response Analysis in Linear Multivariate Models. Economics Letters, 58, 17-29.

51. Rating and Valuation Department, http://www.rvd.gov.hk

52. Renaud, B.; F. Pretorius and B. Pasadilla, 1997, Markets at work: dynamics of the residential real estate market in Hong Kong, Hong Kong: Hong Kong University Press.

53. Subrahmanyam, A., 2007. Liquidity, Return, and Order-flow Linkages between REITs and the Stock Market. Real Estate Economics, 35(3), 383-408.

54. Tsang, J., Budget Speech 2010-11, http://www.budget.gov.hk/2010

55. Tse, C. Y. and C. K. Y. Leung, 2002, Increasing Wealth and Increasing Instability: the role of collateral, Review of International Economics, 10(1), 45-52.

56. Wessel, D., 8 April 2010. Did ‘Great Recession' Live Up to the Name? Wall Street Journal. 
57. Wong, G., 2010, Three Essays on Housing Market in Hong Kong: Implications for Public Policy and Macro Economy," Lingnan University, Hong Kong.

58. Yam, J., Chairman of Hong Kong Monetary Authority, 14 October 1998, "Defending Hong Kong's Monetary Stability", http://www.info.gov.hk/hkma.

59. Yiu, M., A. Ho, Y. Ma and S. K. Tsang, 2010, Hong Kong Linked Exchange Rate System and Hong Kong Dollar Exchange Rate Dynamics under Strong Capital Inflows, Hong Kong Monetary Authority, mimeo. 


\section{Exhibit 7.1}

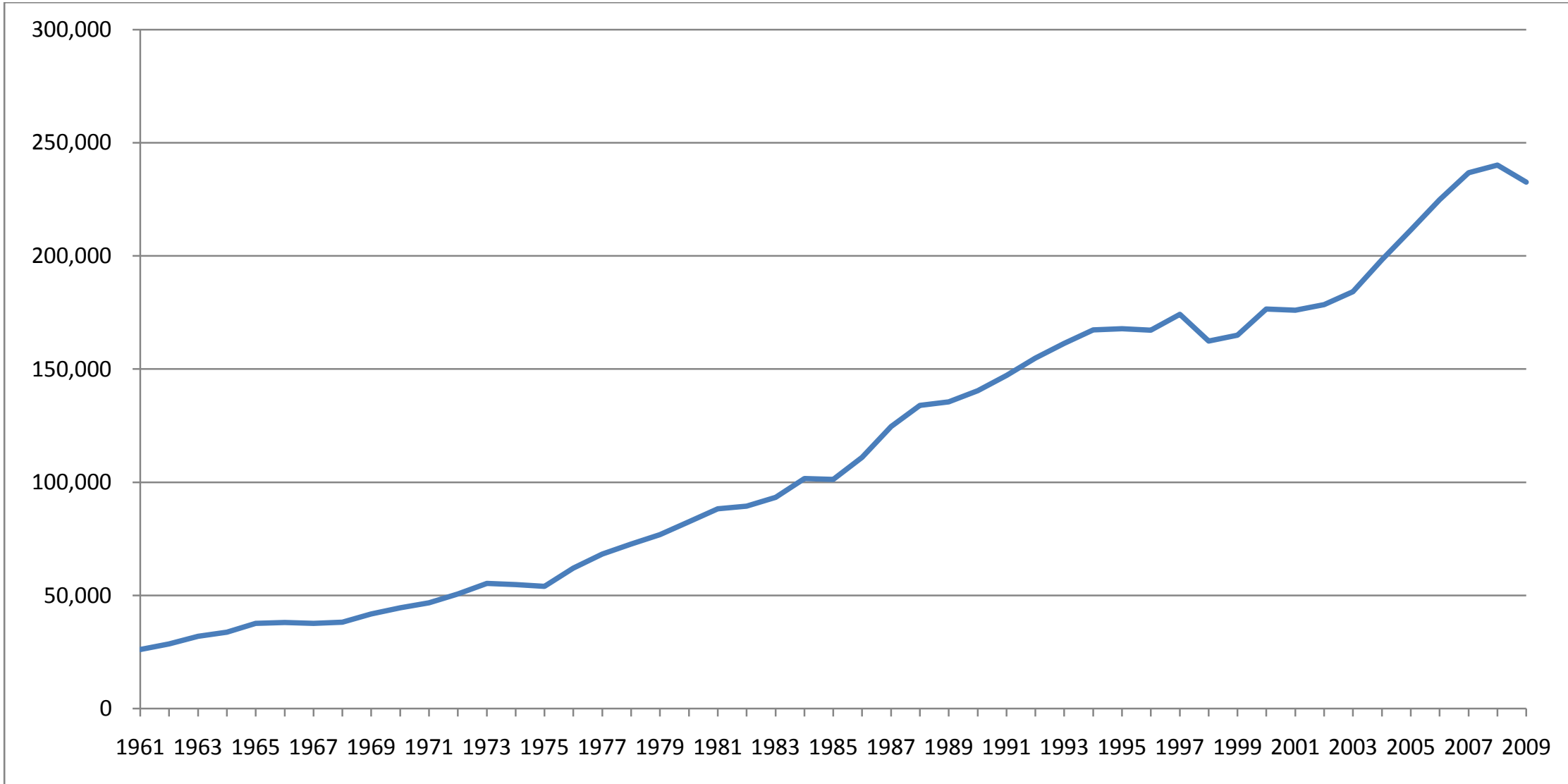




\section{Exhibit 7.2}

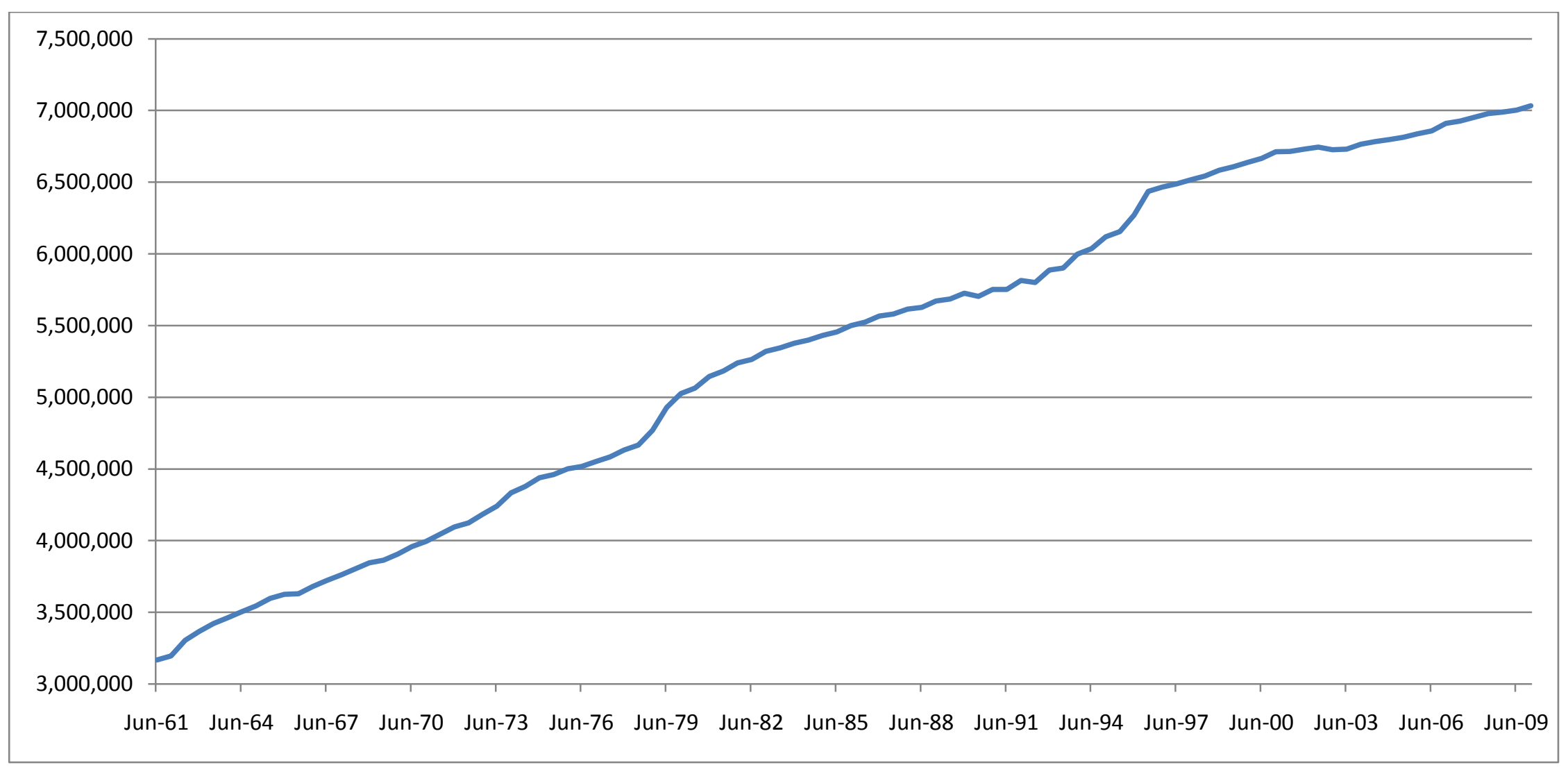




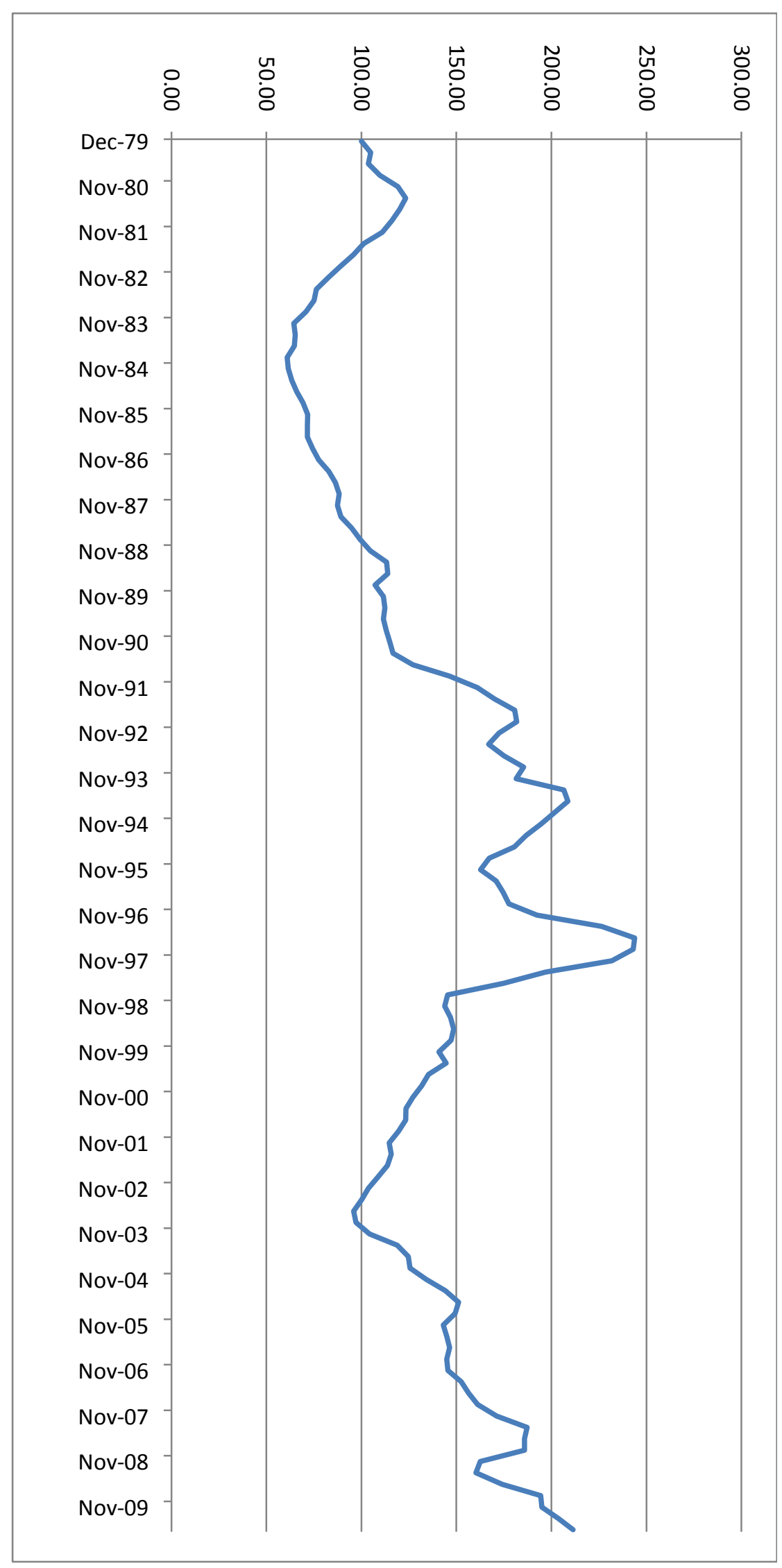




\section{Exhibit 7.4}

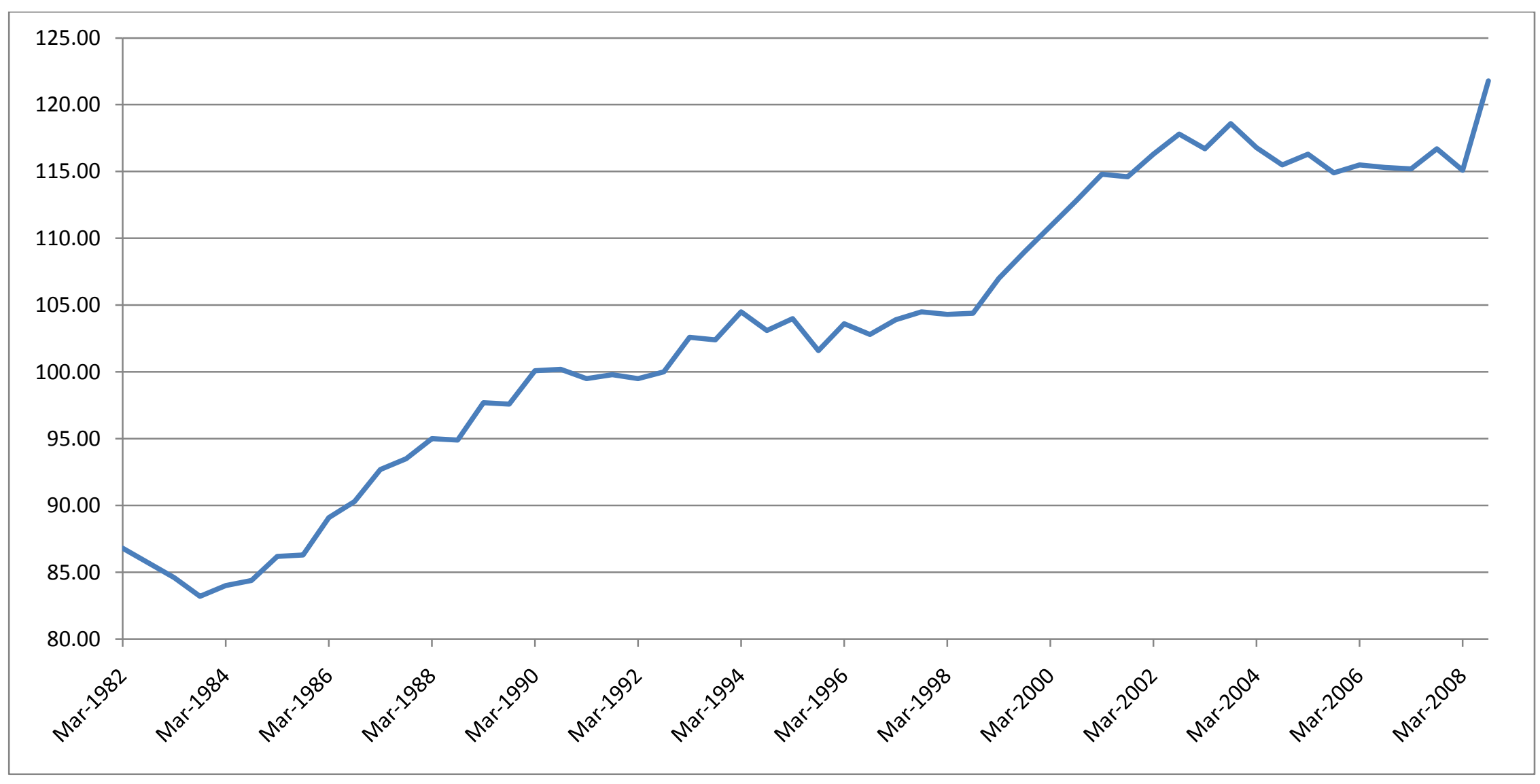




\section{Exhibit 7.5}

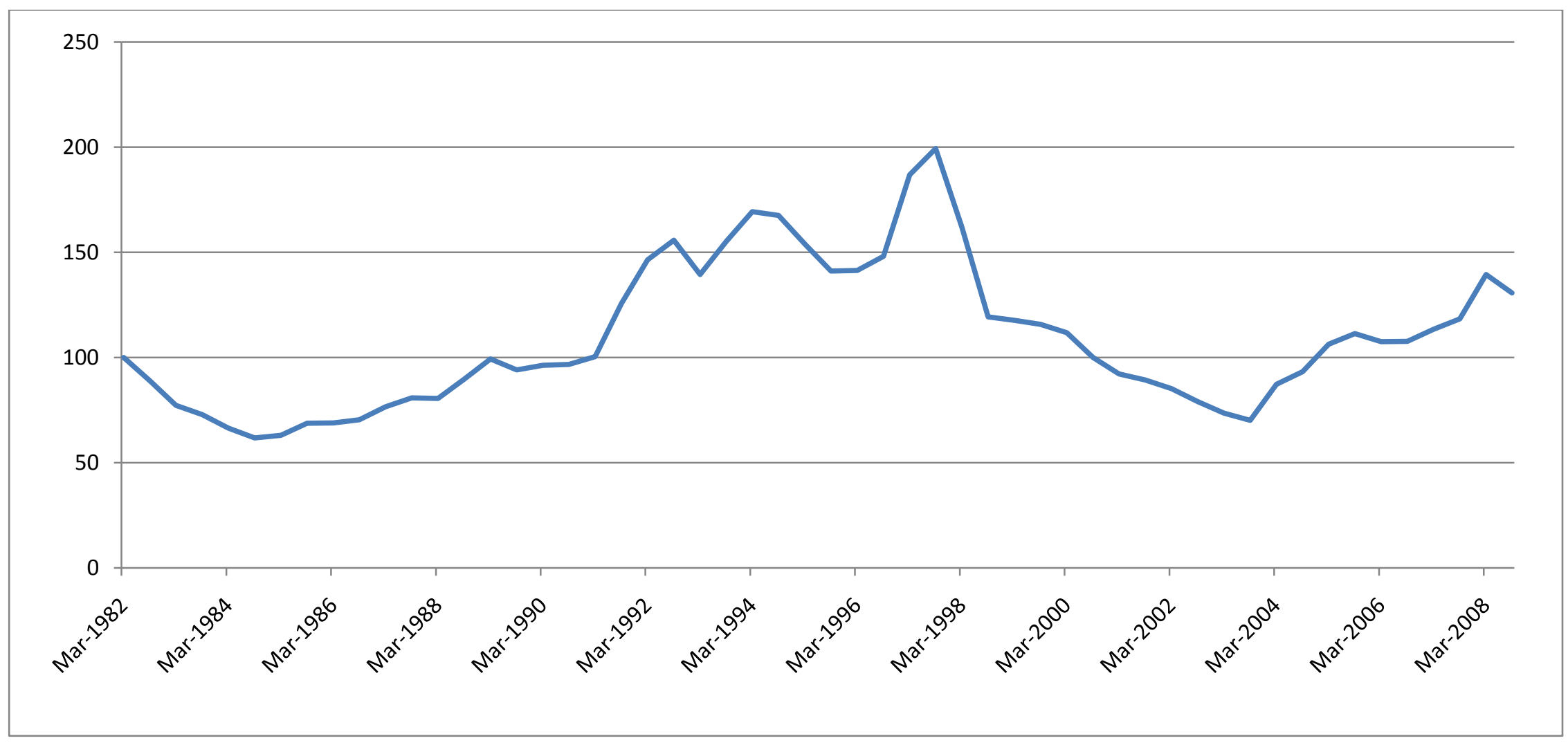




\section{Exhibit 7.6}

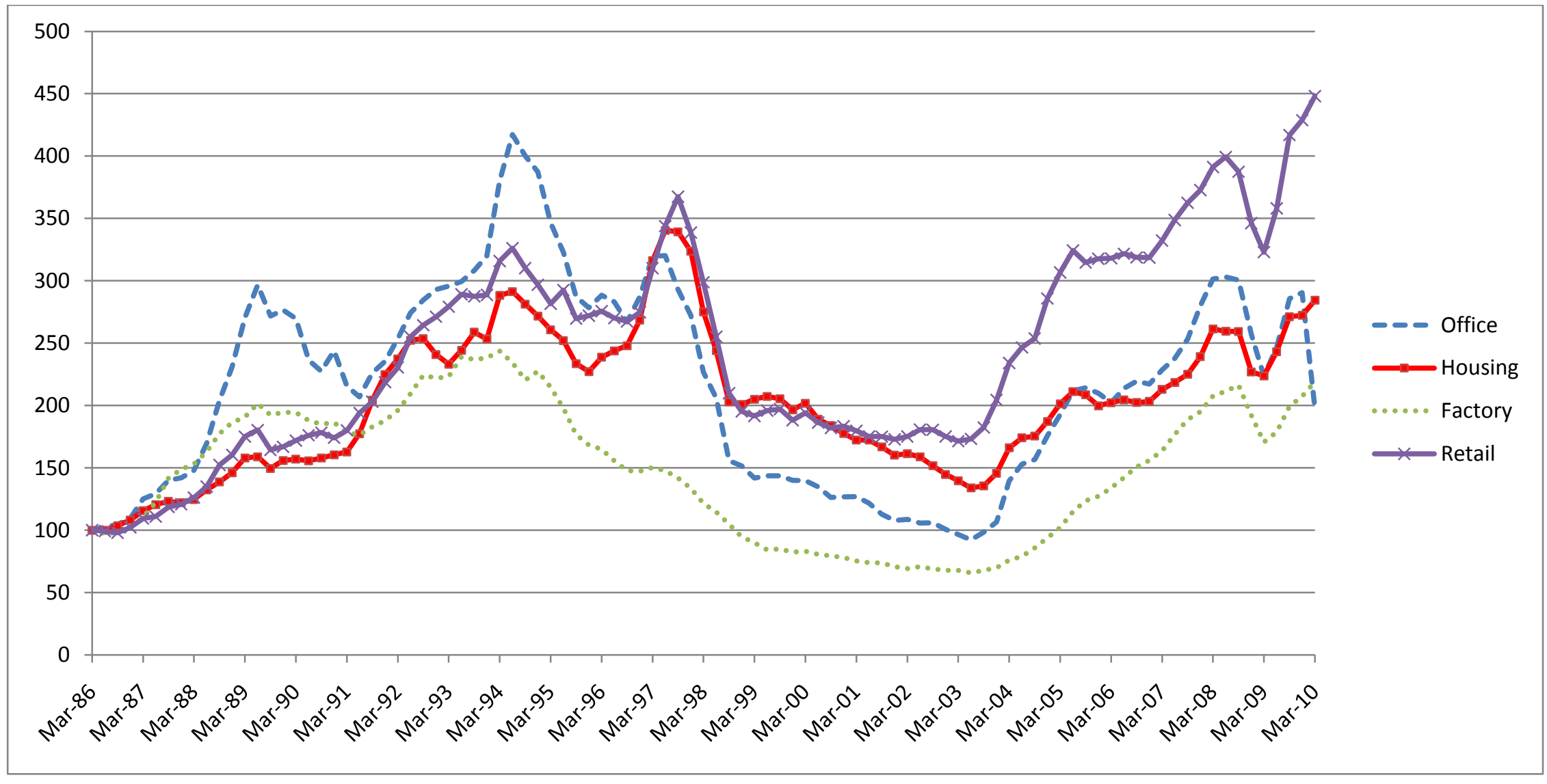




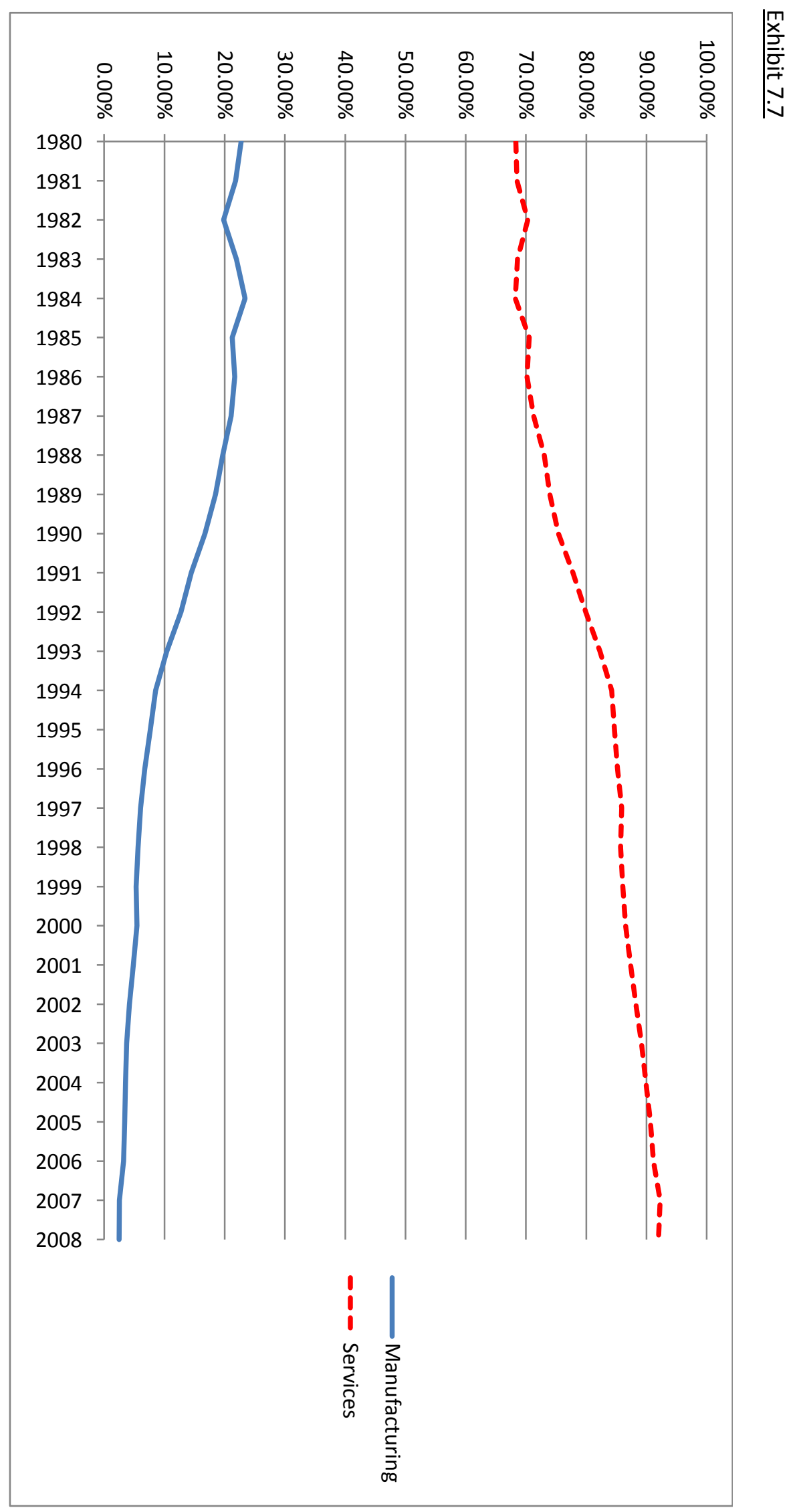




\section{Exhibit 7.8}

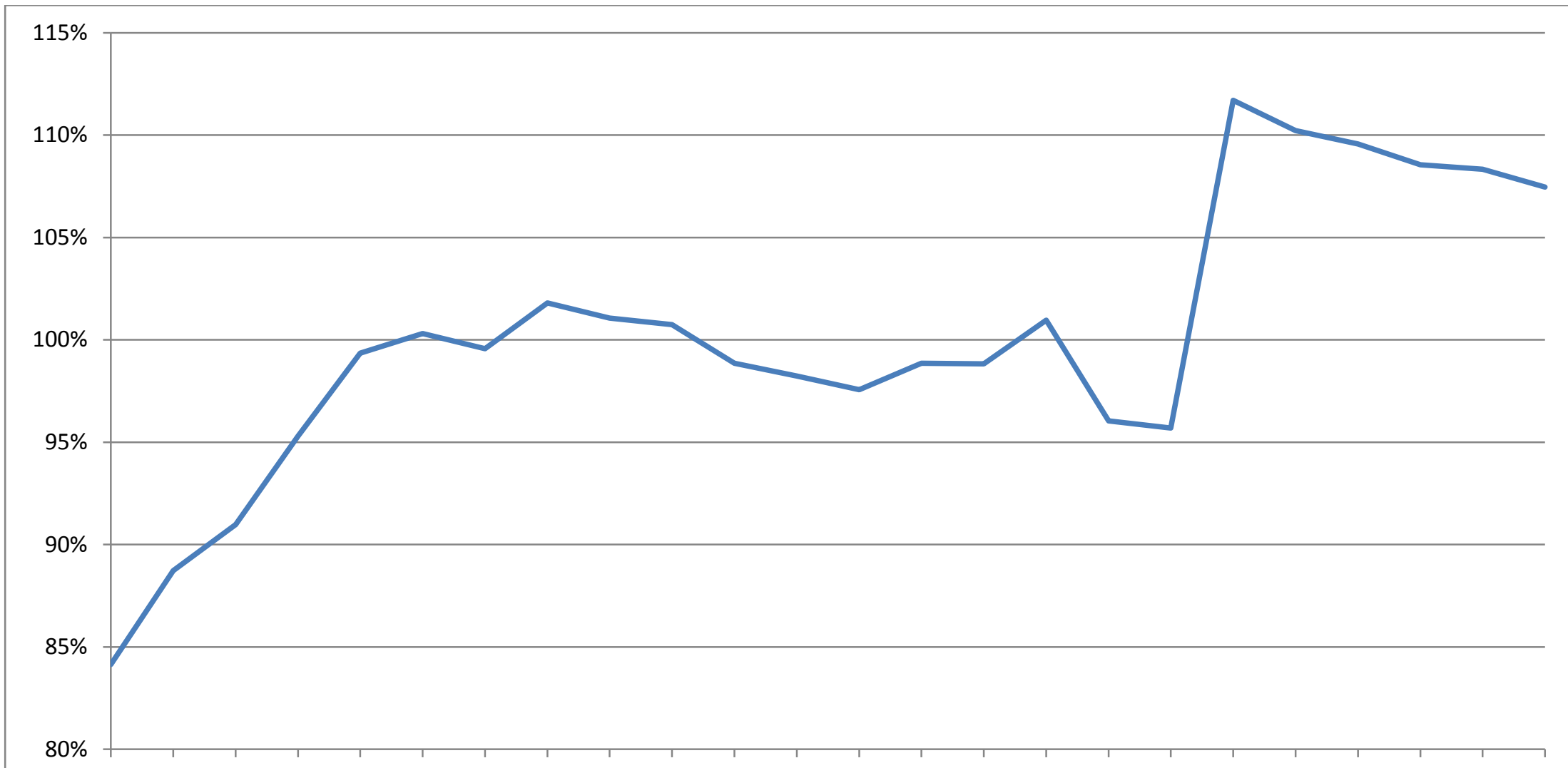

198619871988198919901991199219931994199519961997199819992000200120022003200420052006200720082009 


\section{Exhibit 7.9}

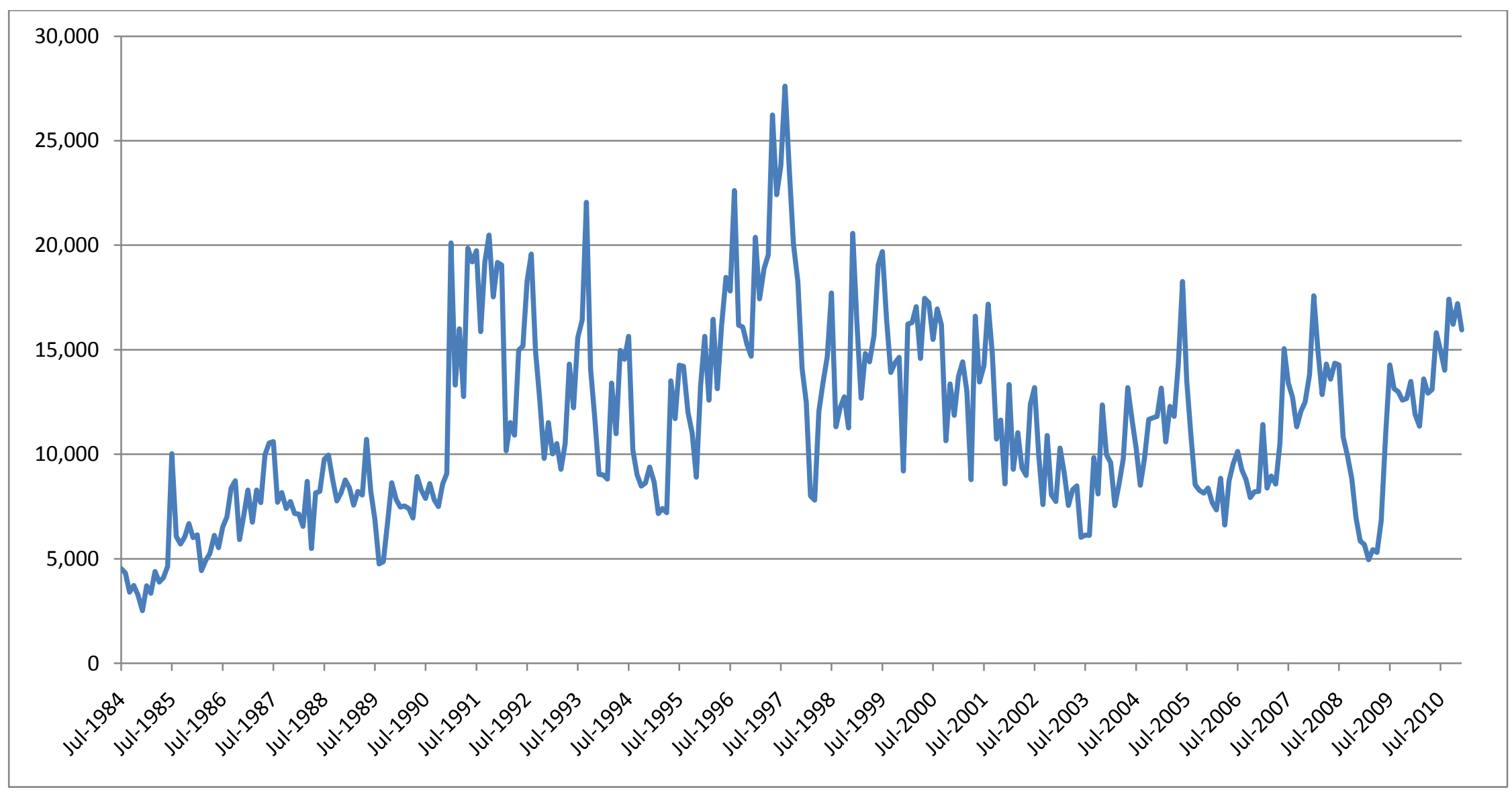




\section{Exhibit 7.10}

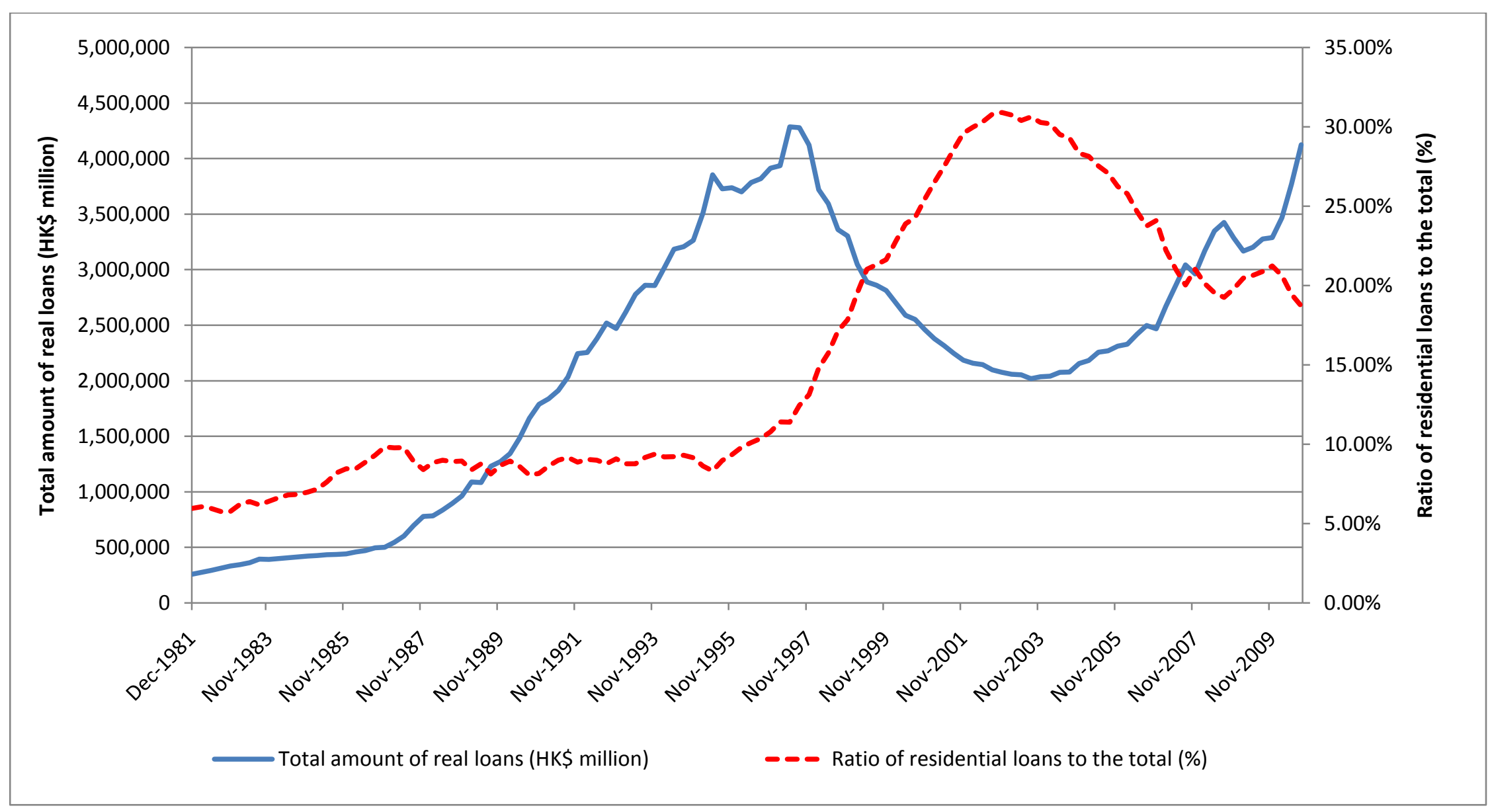




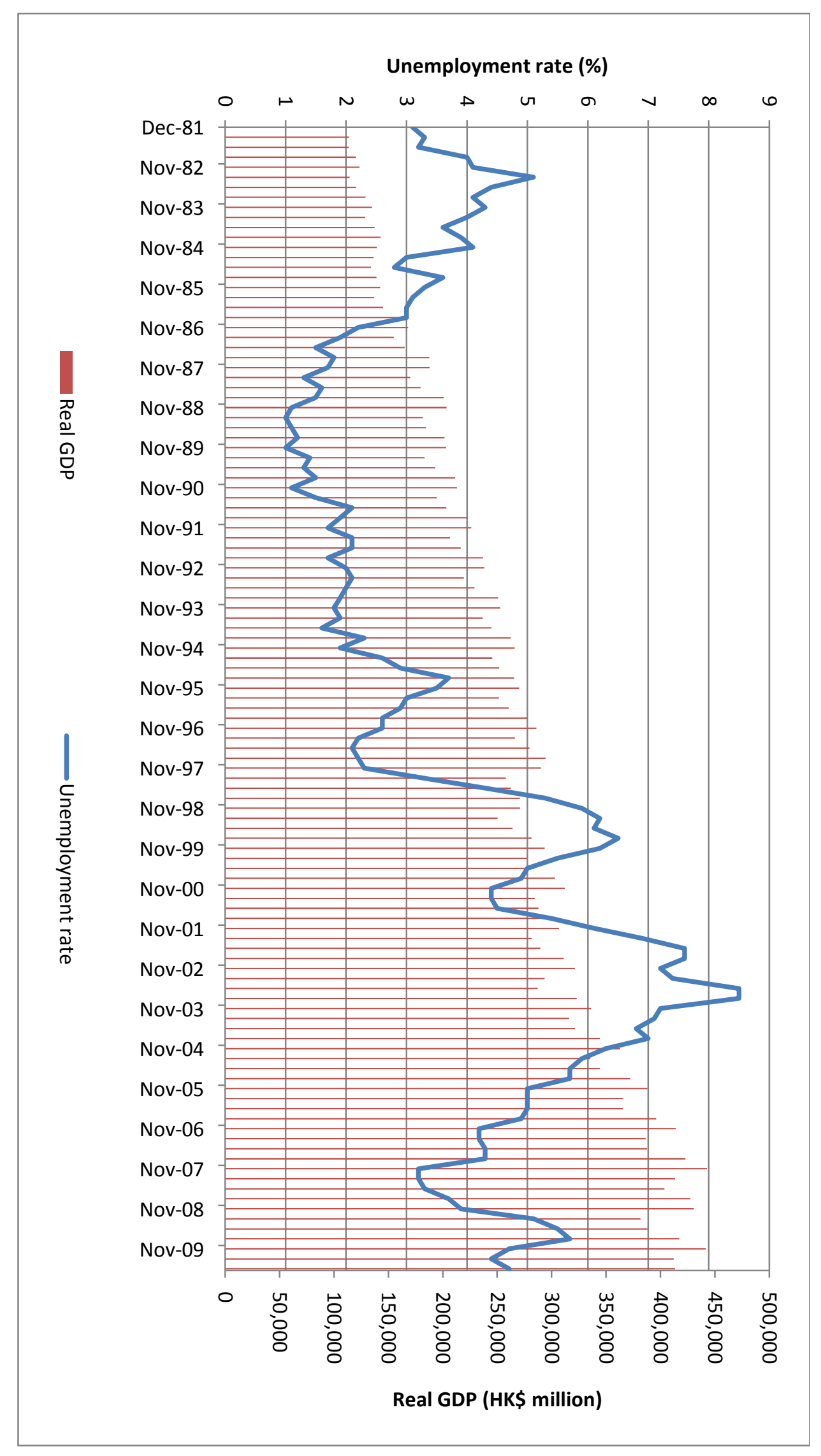

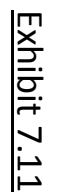




\section{Exhibit 7.12}

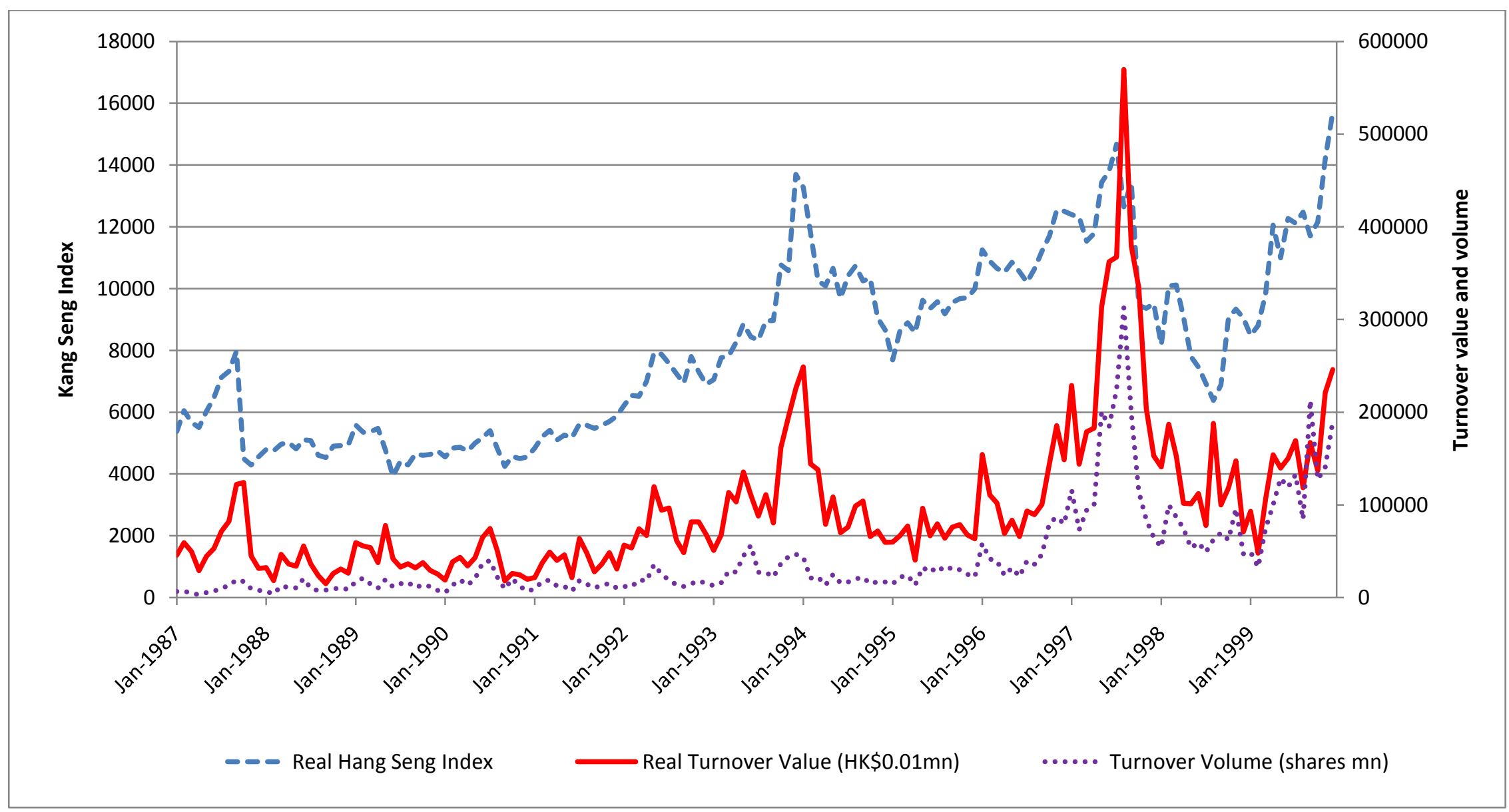




\section{Exhibit 7.13}

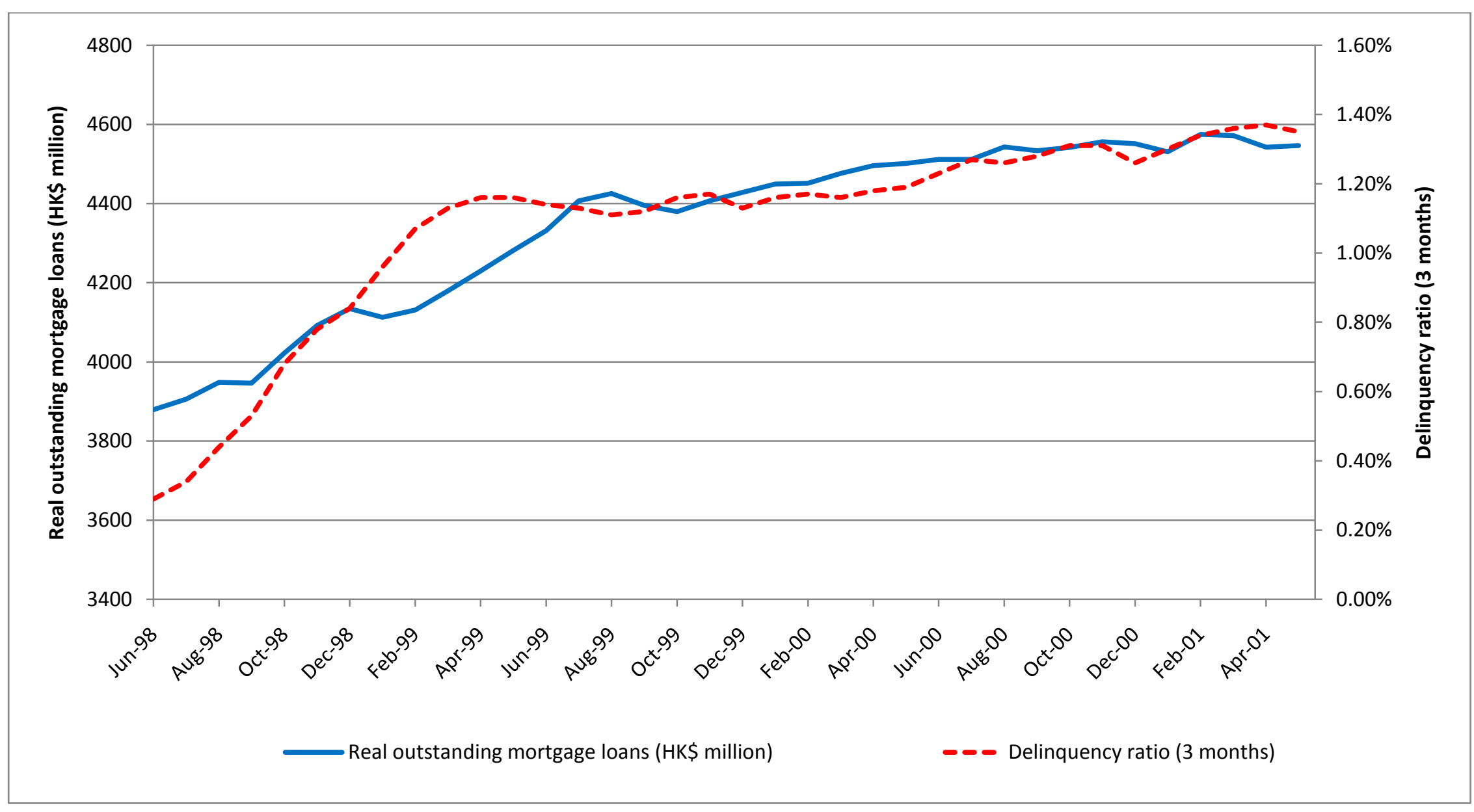


Exhibit 7.14a

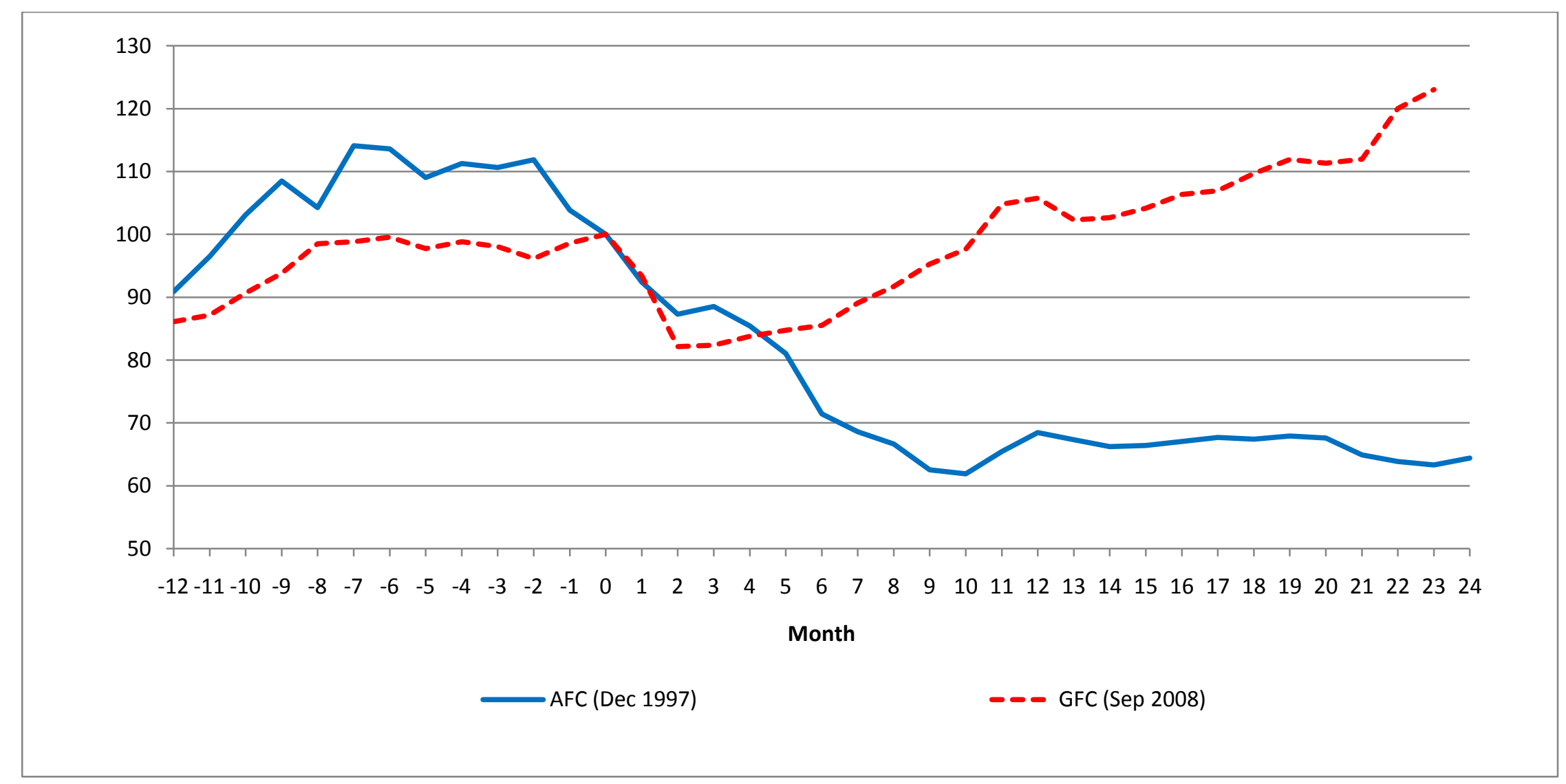


Exhibit 7.14b

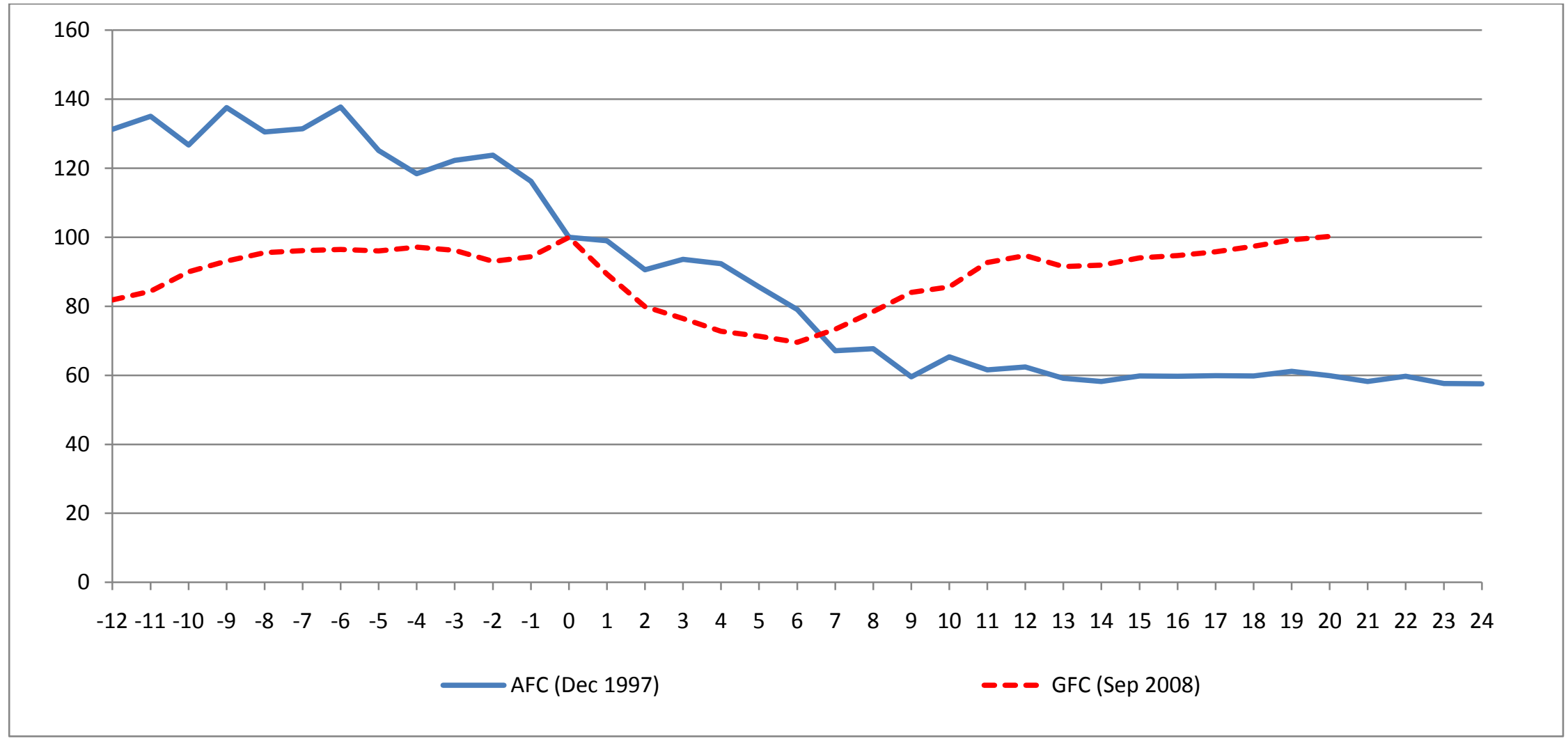




\section{Exhibit 7.14c}

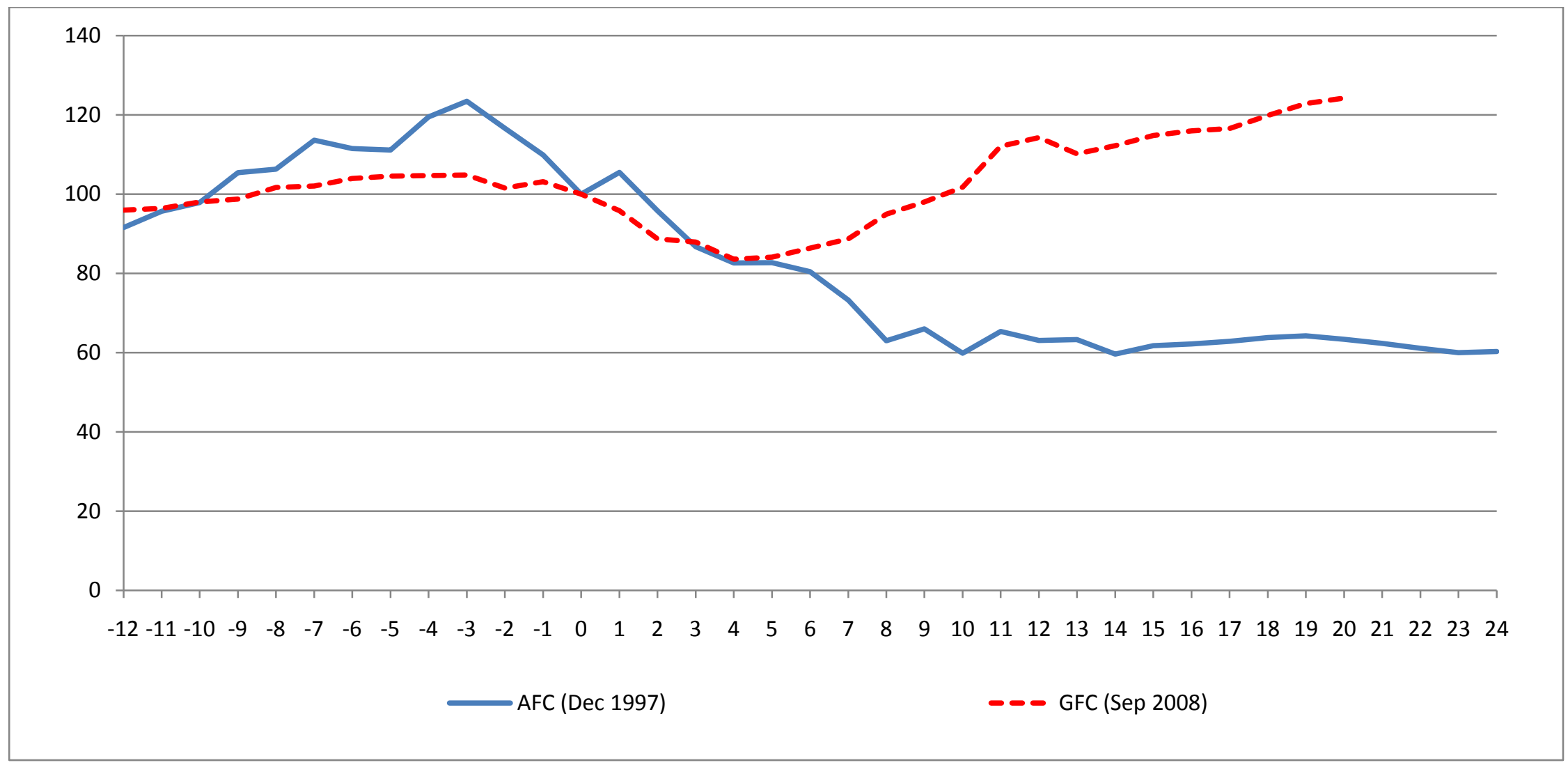




\section{Exhibit 7.14d}

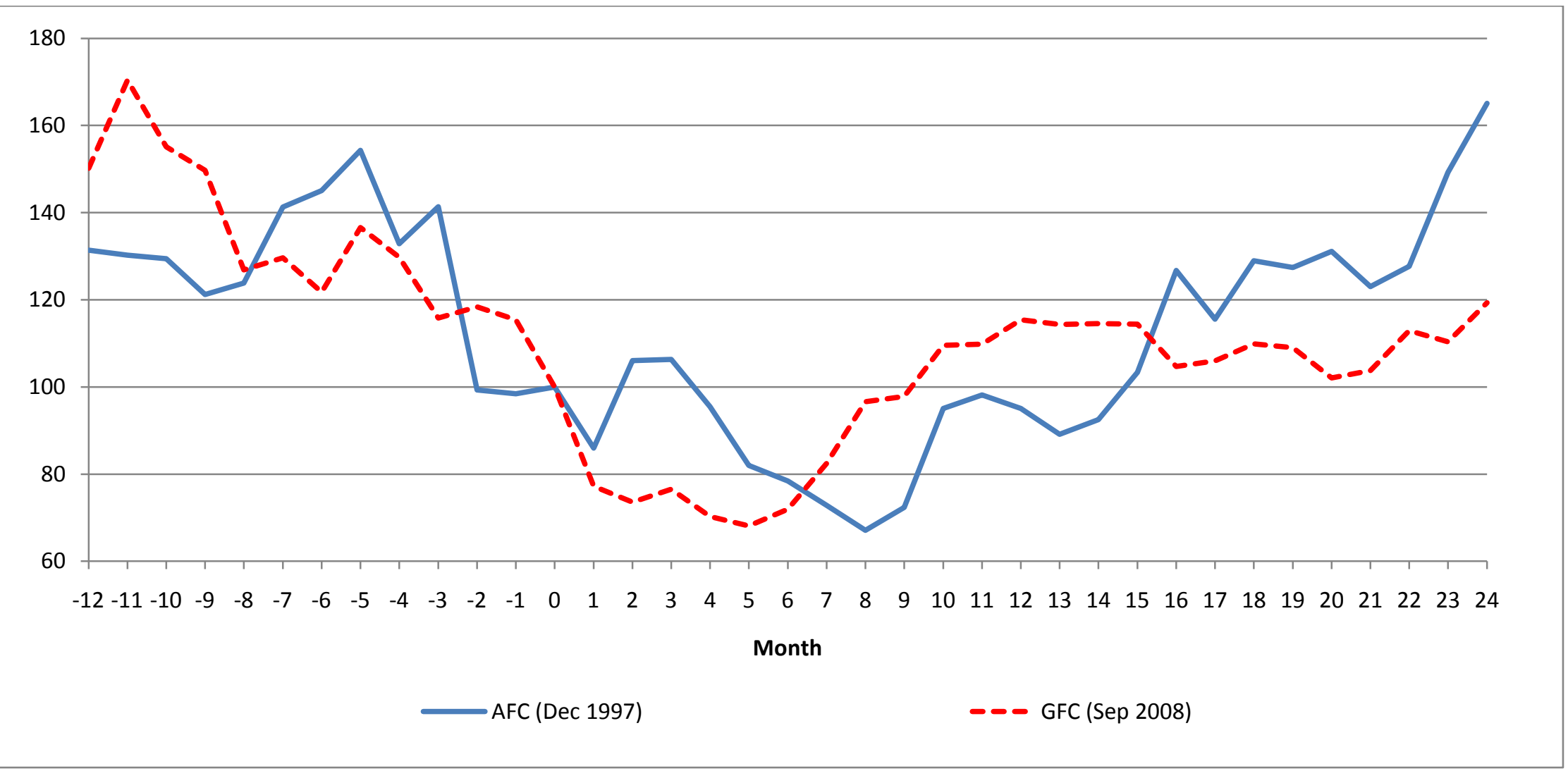




\section{Exhibit 7.14e}

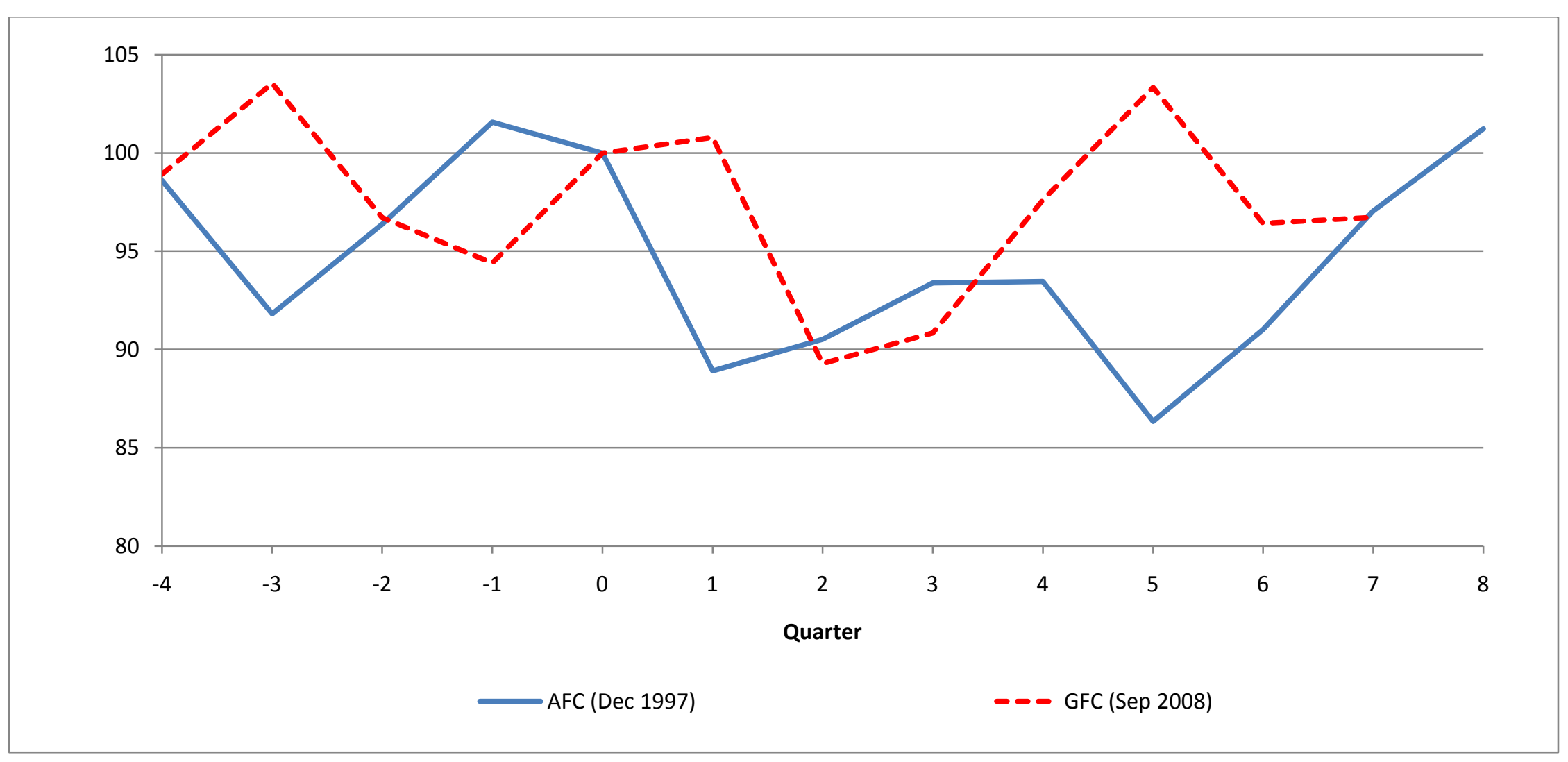


Exhibit 7.14f

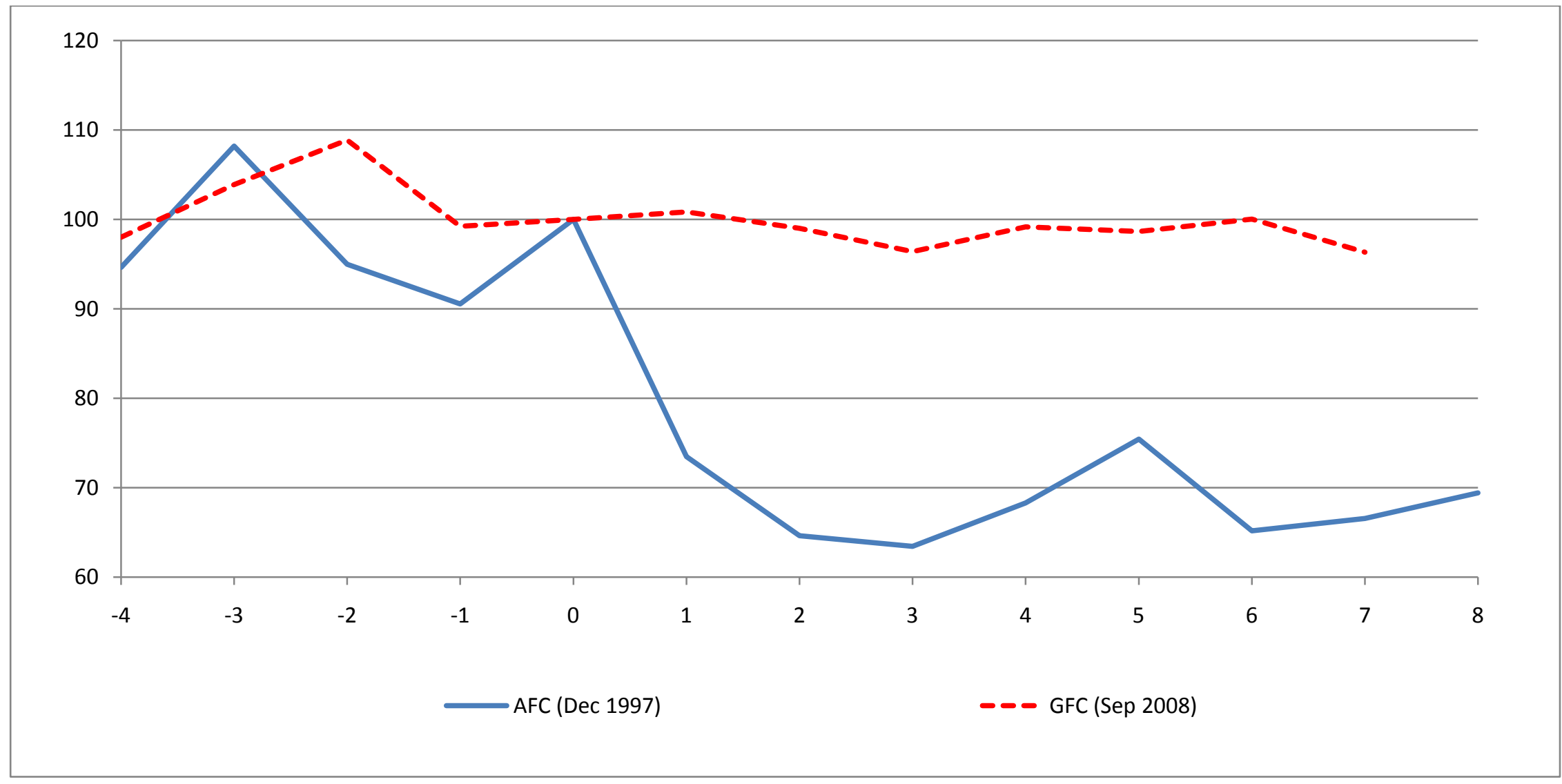


Exhibit 7.14g

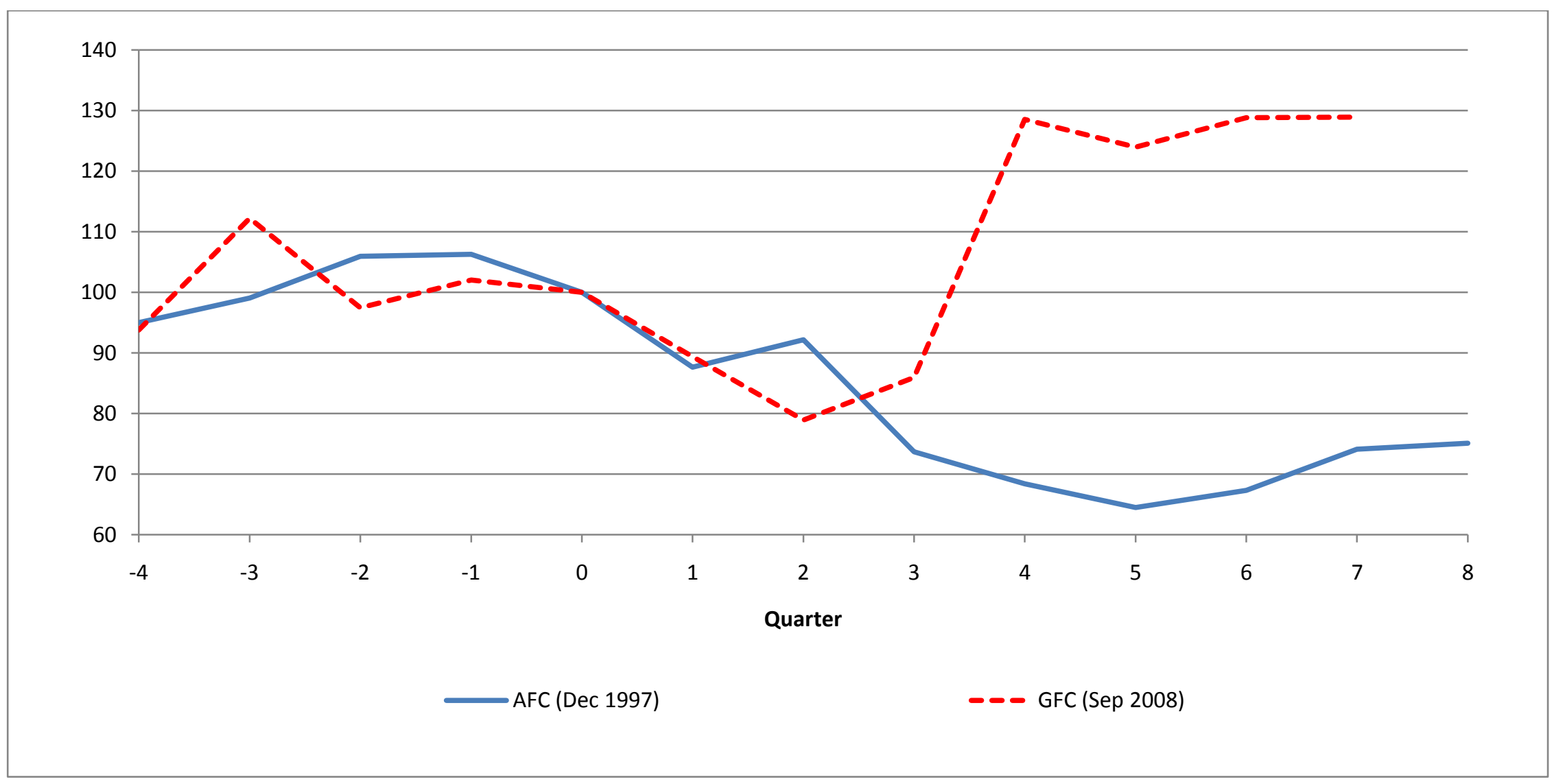


Exhibit 7.14h

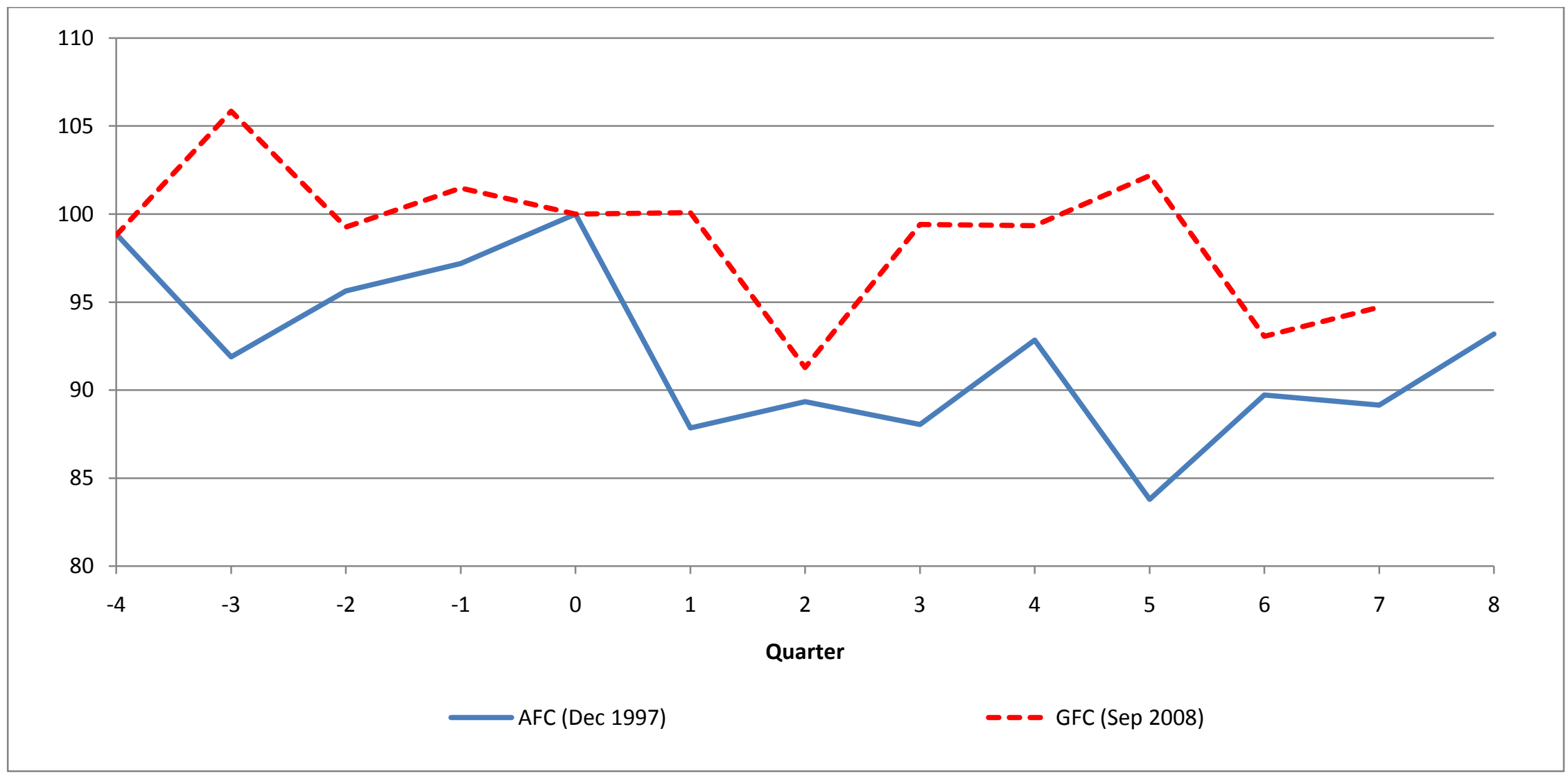


Exhibit 7.14i

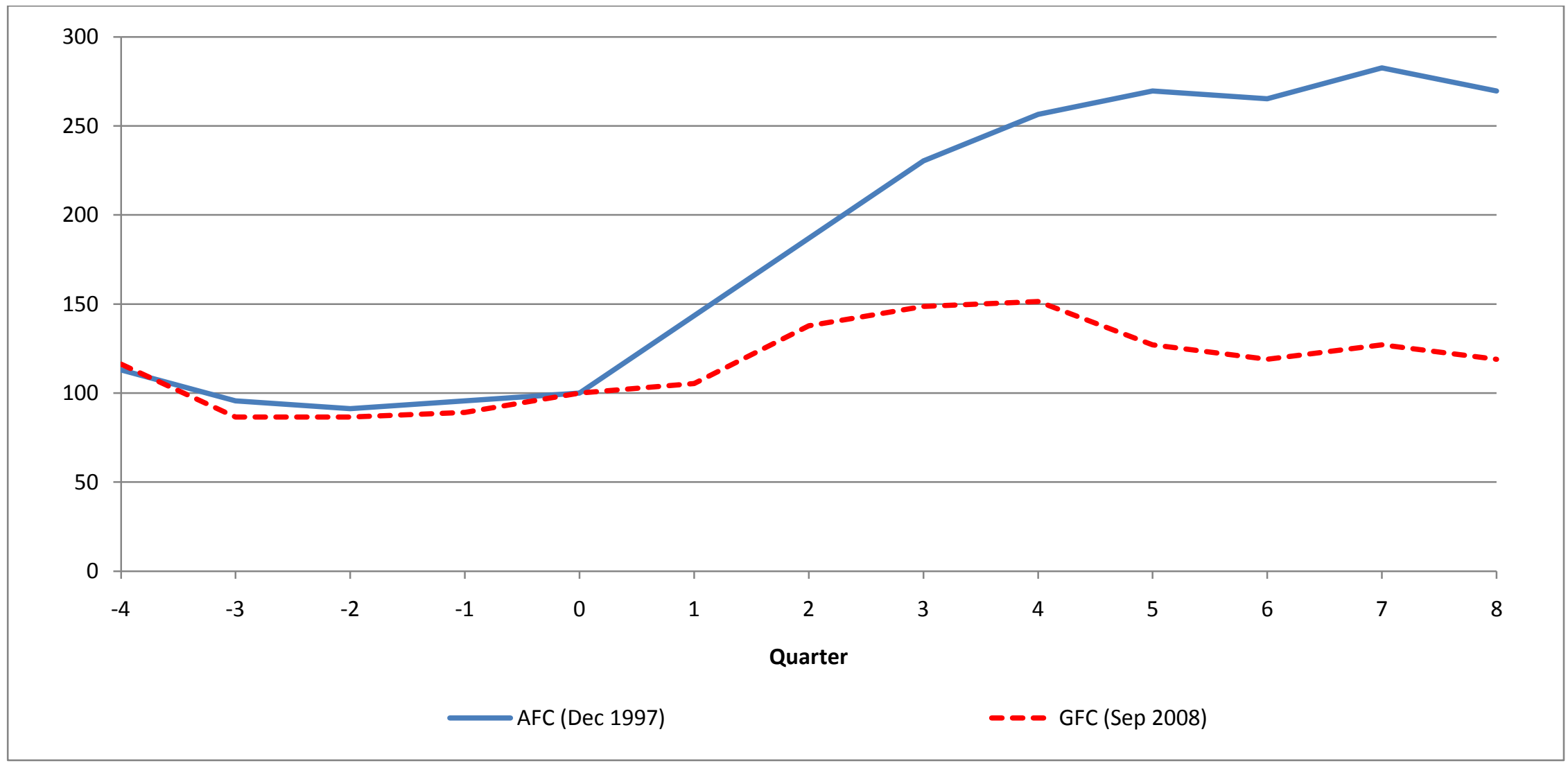




\section{Exhibit 7.14j}

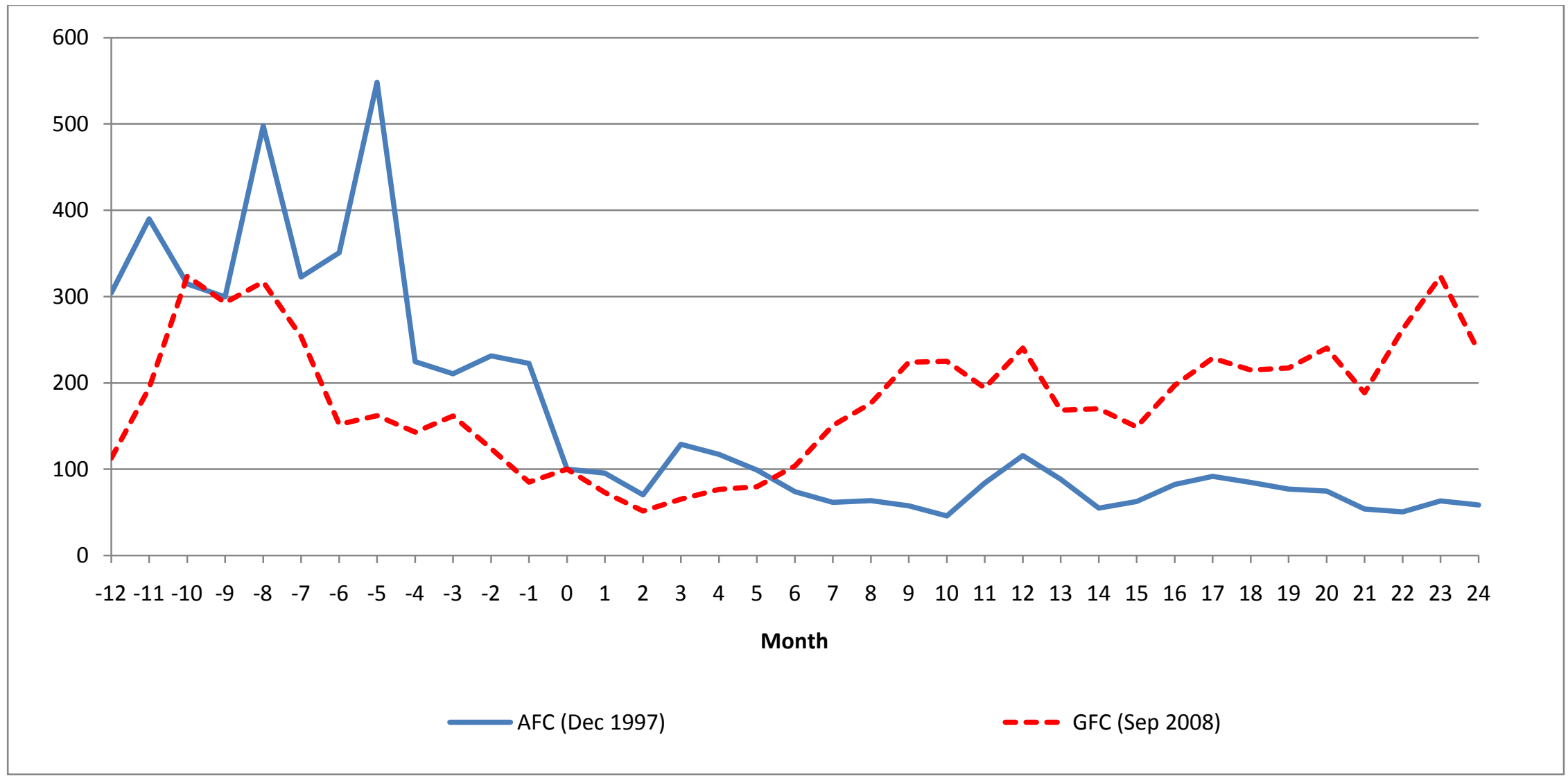




\section{Exhibit 7.14k}

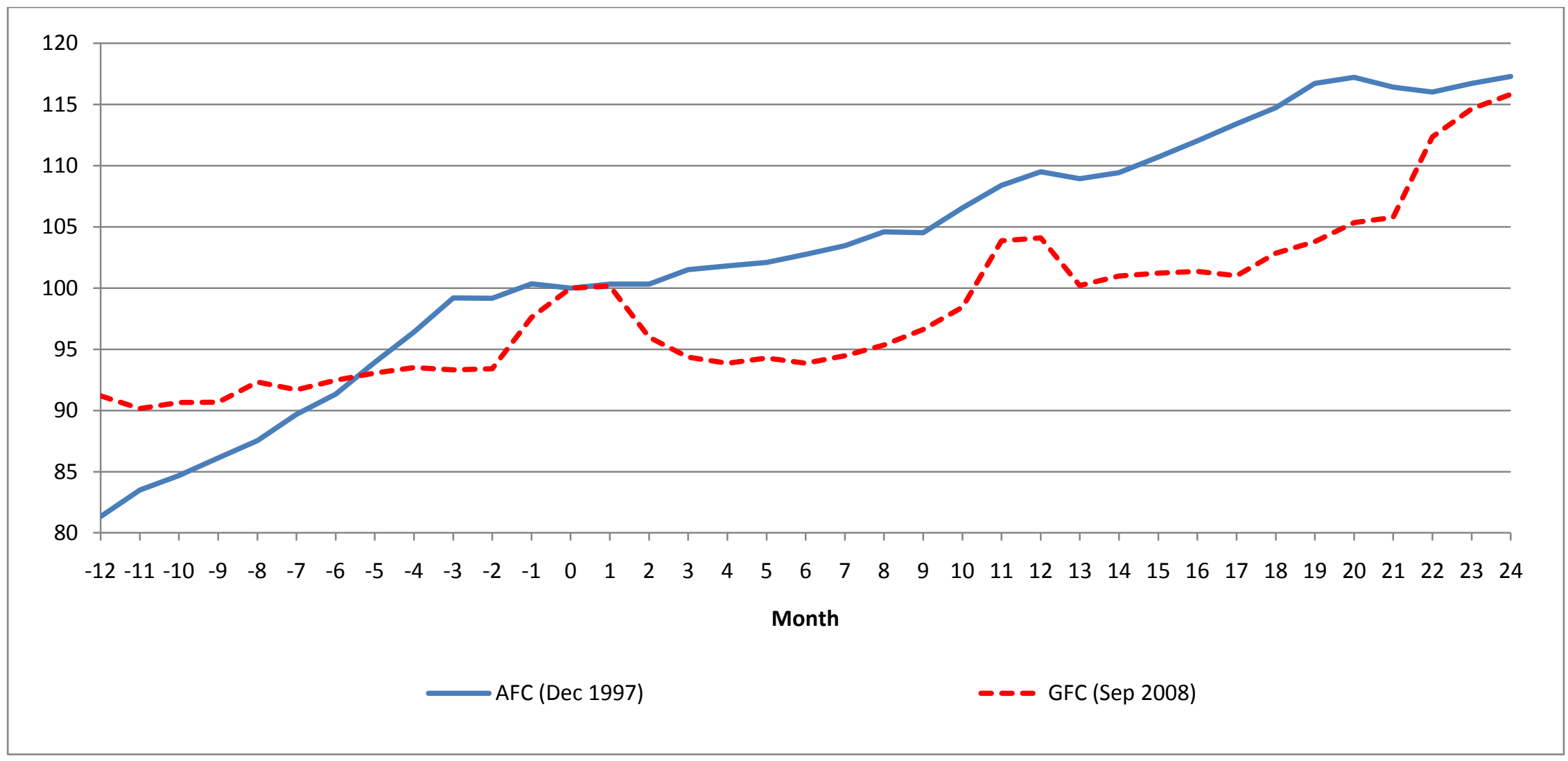


Exhibit 7.14l

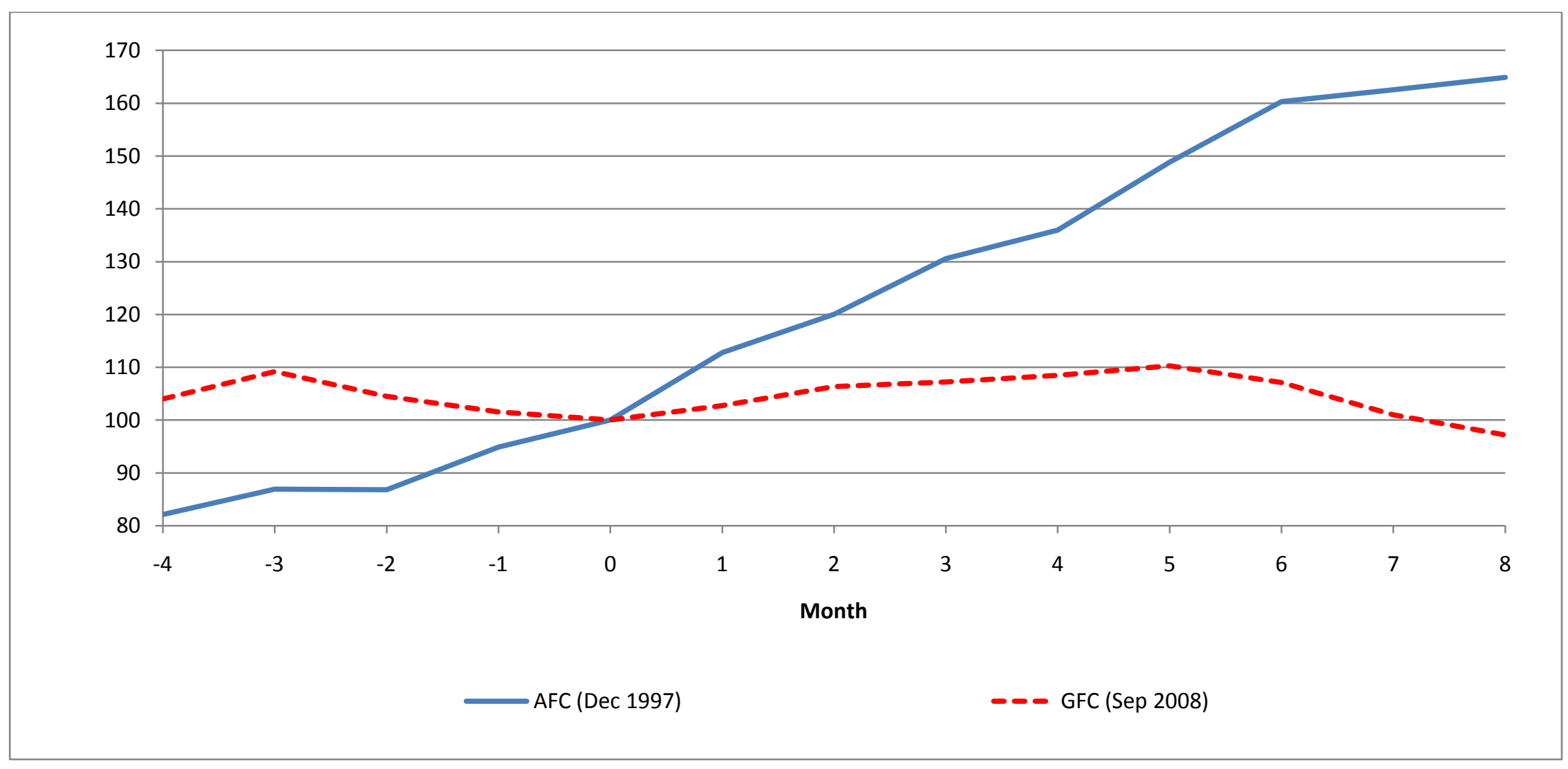




\section{Exhibit $7.14 \mathrm{~m}$}

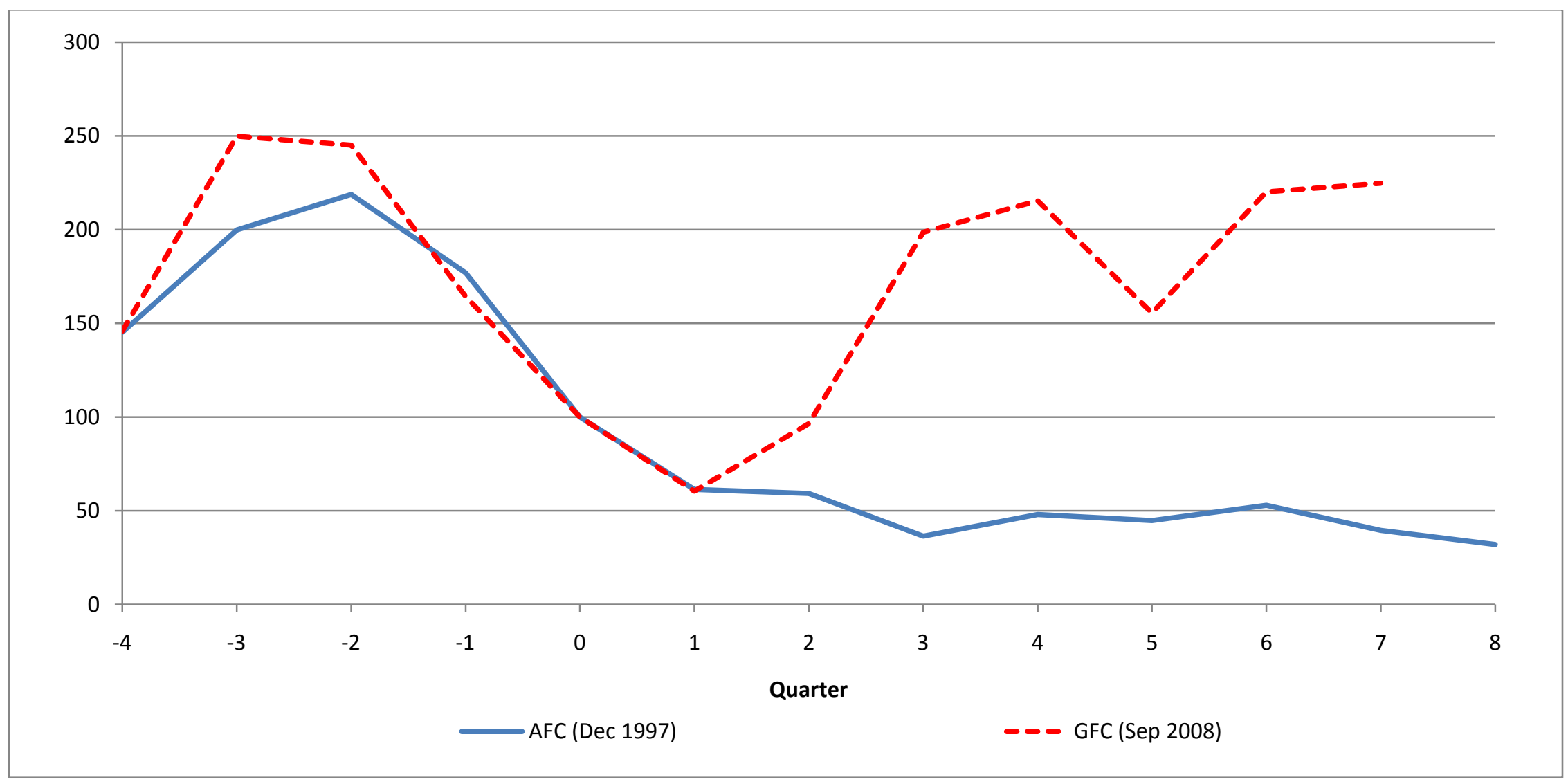


Exhibit 7.14n

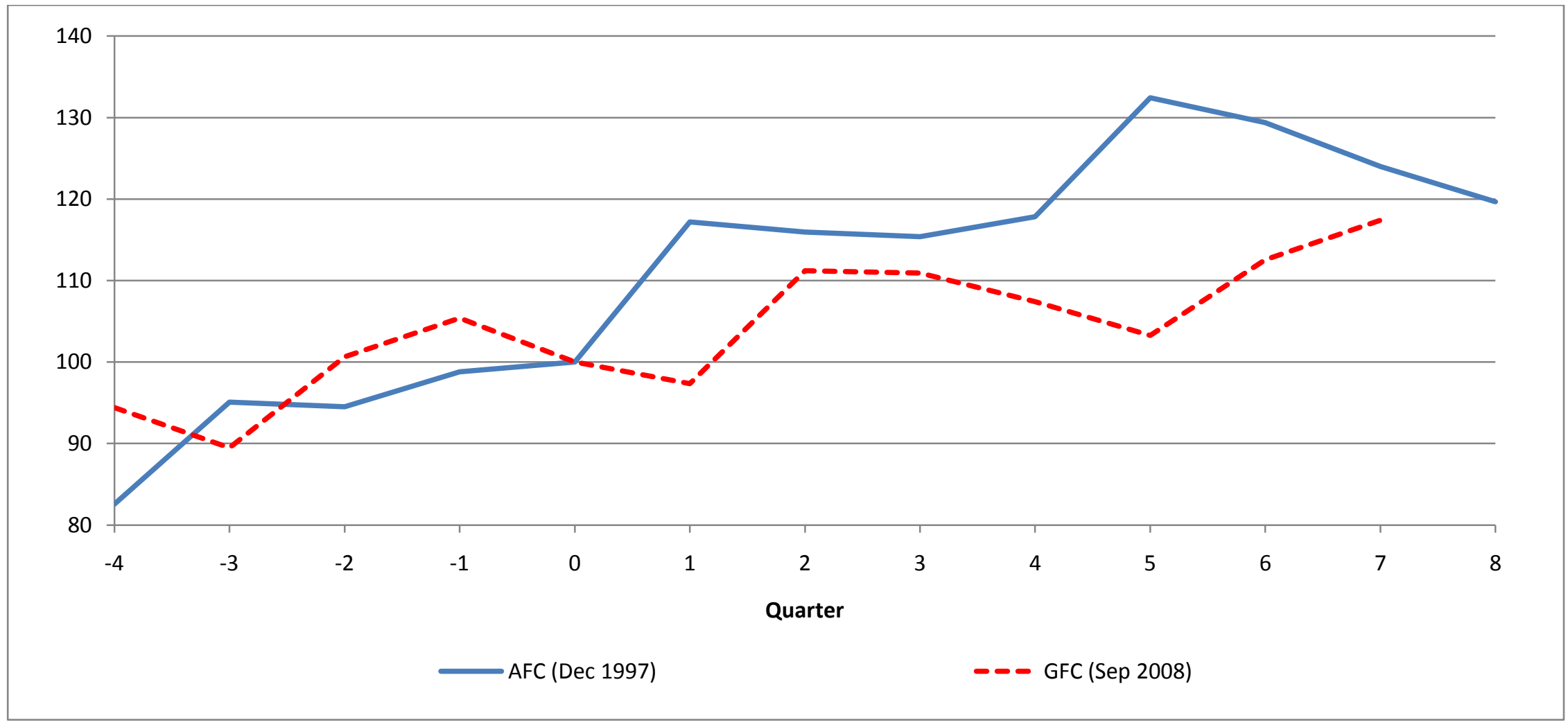

